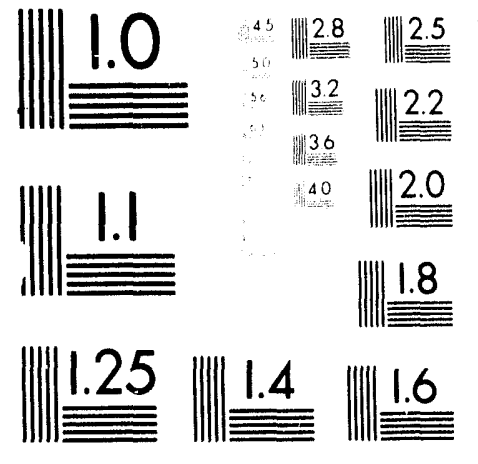



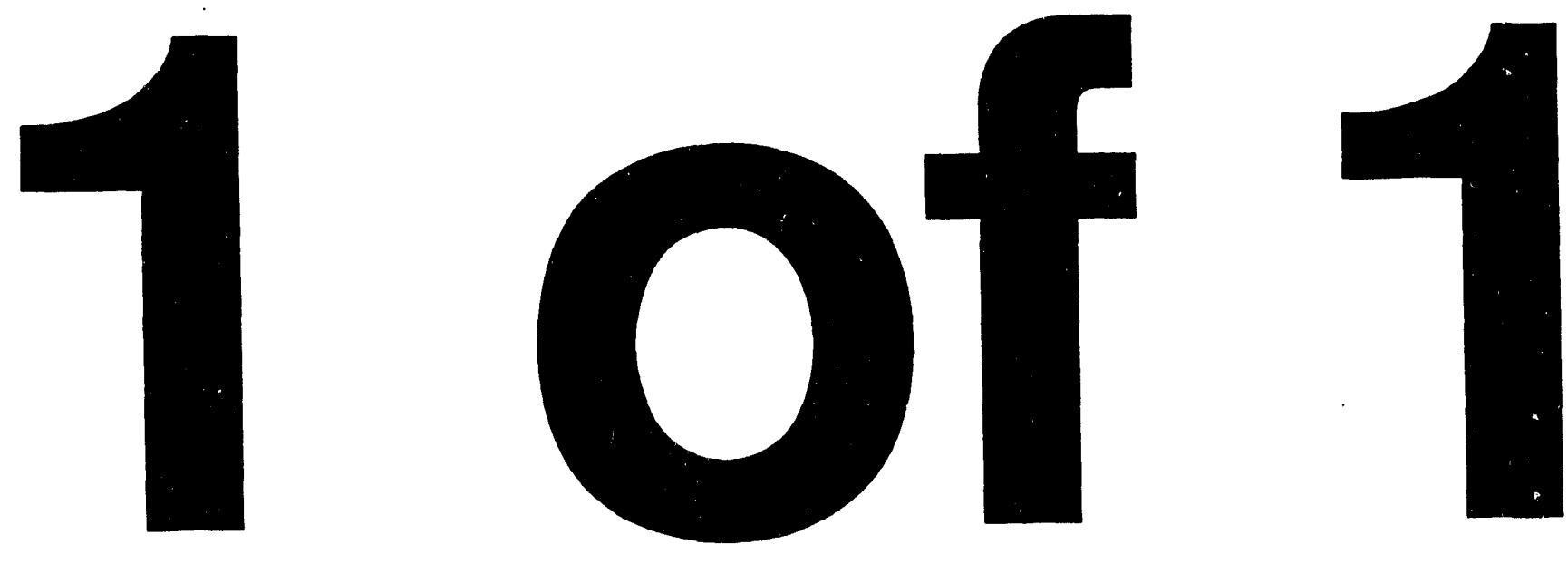


\section{Electric Utility System Master Plan}

\section{October 1992}

Prepared by:

O. Meredith Erickson, PE

Electric Utility System Engineer
Approved by:

W. Lee McVey, PE Electric Utility System Manager

David K. Johnson, PE Electric Utility Division Leader

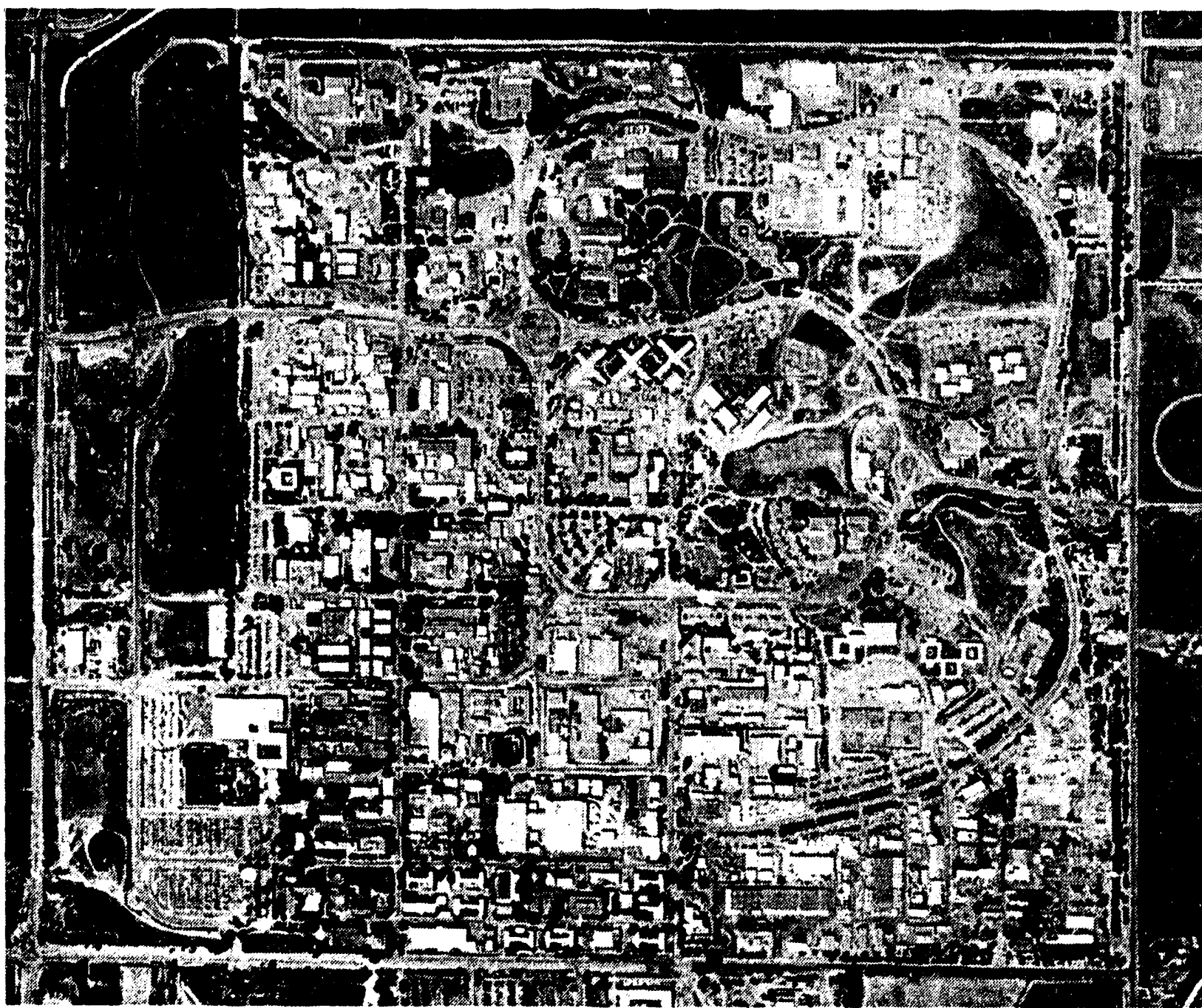

LAWRENCE LIVERMORE NATIONAL LABORATORY University of California • Livermore, California • 94550 


\section{Introduction}

Proper planning for electric utilities is one of the most important considerations for providing adequate and reliable electric service to any facility. At Law rence Livermore National Laboratory (LLNL), a multidiscipline institution involved in large-scale applied research and development programs, great importance is given to the pl..nning, acquisition, operation, and maintenance of the electric utility system to achieve the mission of the Laboratory.

The goal of this Master Plan is to provide guidelines which will continue to ensure that reliable electrical service will be available to accommodate the growth of the Laboratory and to fulfill all predictable future programmatic needs.

The Master Plan has been organized into the following sections:

- Section 1: General information, LLNL history and background data, and the history and availability of the electric utility supply.
- Section 2: Existing conditions, including an operational description and operating constraints.

- Section 3: Planning analysis, providing historical and predictable future energy requirements, and the rationale for various proposals to resolve present and future problem areas.

- Section 4: Long-range plan, site development, and the proposed improvements and expansions required.

- Section 5: Five-year plan, descriptions, definitions, including facilities required for funded programmatic needs and electric utility system reinforcemen ، requirements as planned and funded by the approved Line Item Electrical Power System Replacements and Upgrades (EPSRU). Additional General Plant Project (GPP) proposals have also been included. 


\section{Contents}

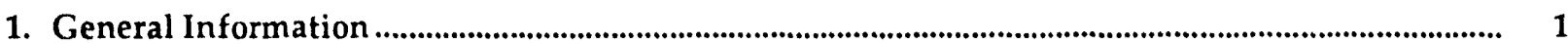

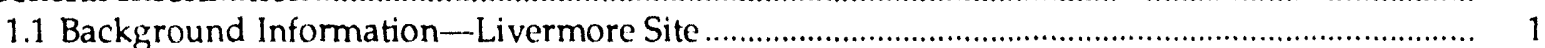

1.1.1 General.

1.1.2 Location

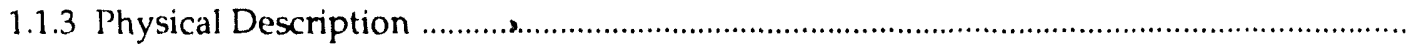

1.1.4 Programs.

1.1.5 Population

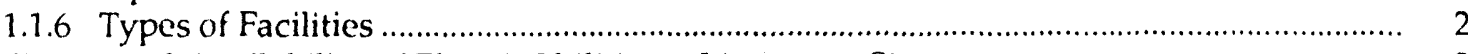

1.2 History and Availability of Electric Utilities -Livermore Site ................................................. 2

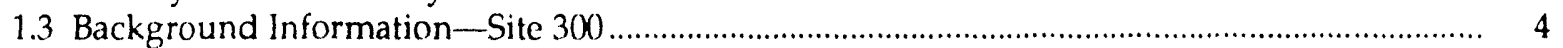

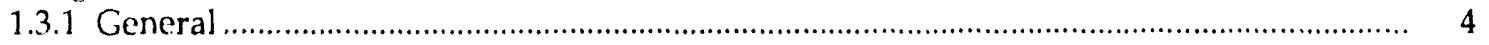

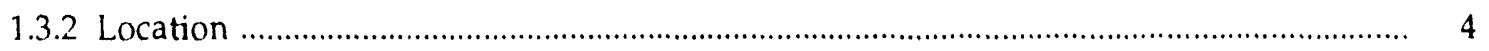

1.3.3 Physical Description ................................................................................................. 4

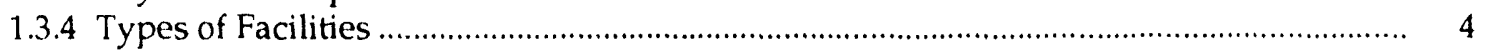

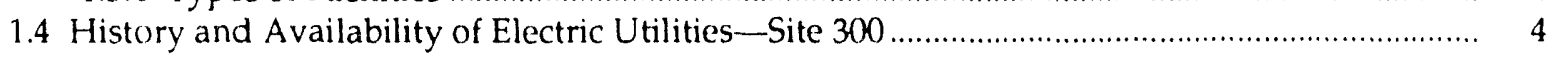

2. Existing Conditions-Description and Operational

Constraints of Existing Electric System ................................................................................................. 5

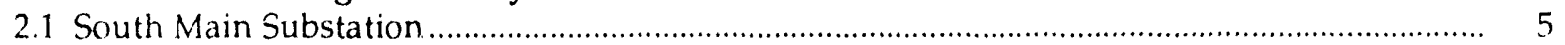

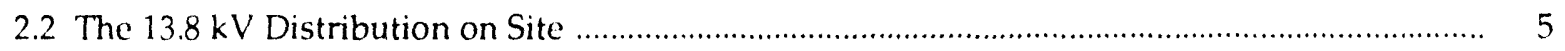

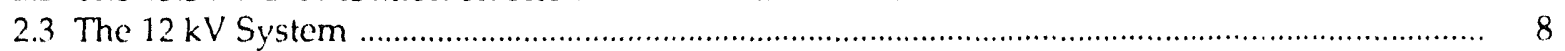

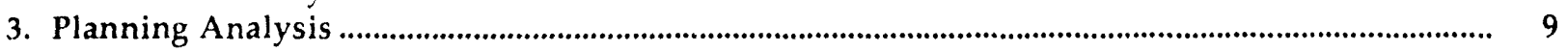

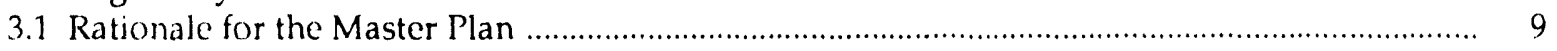

3.2 The Five-Year Plan Includes the Following: ..........................................................................

3.2.1 SF6 Gas-Insulated Substation (GIS) ……..................................................................

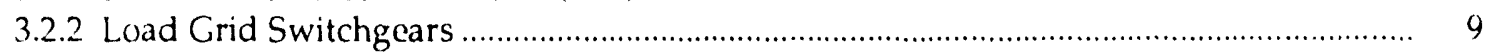

3.2.3 Underground Duct Bank and Manhole System ............................................................ 9

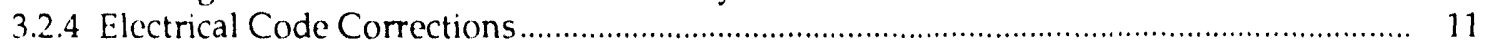

3.2.5 Replacement of Low Voltage Feeders and Panelboards ............................................... 11

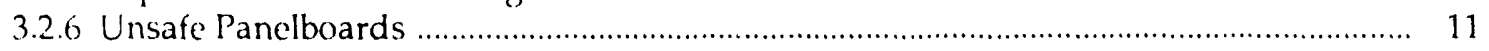

3.2.7 The $12 \mathrm{kV}$ and Overhead Conversion ................................................................ 11

3.3 The Long-Term (Five- to 20-Year) Plan Includes the Following: ............................................. 11

3.3.1 The 13.8 kV Duct Bank and Distribution System ........................................................ 11

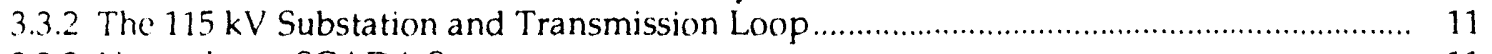

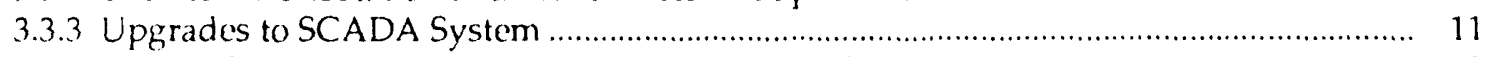

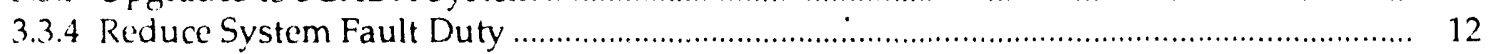

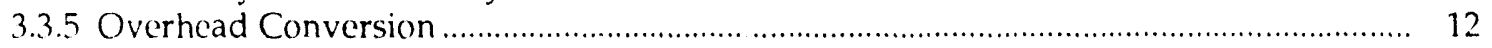

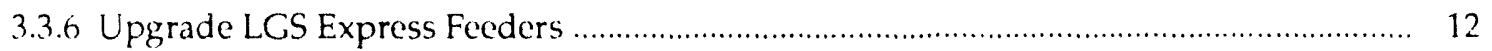

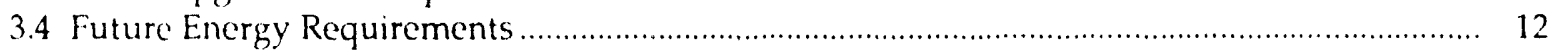

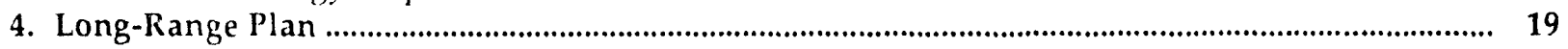

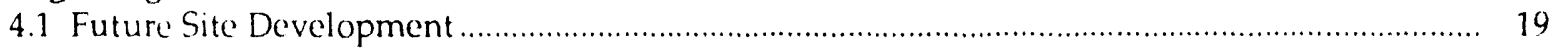

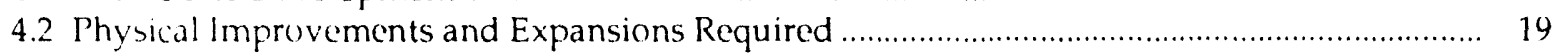

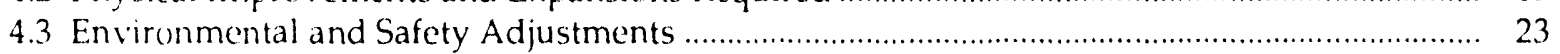

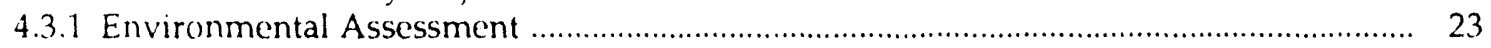

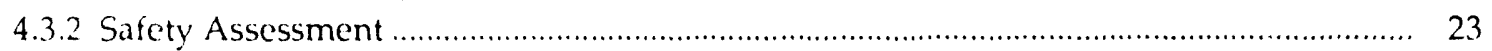

5. Five-Year Plan Projects ................................................................................................................... 24

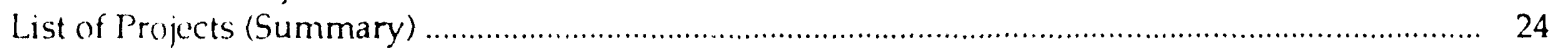

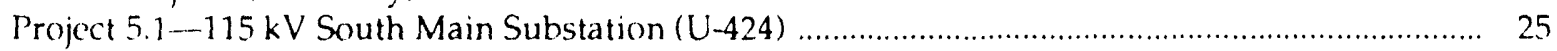

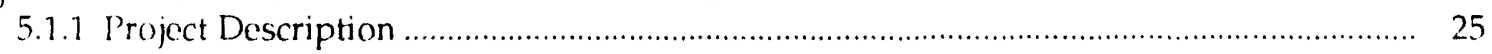

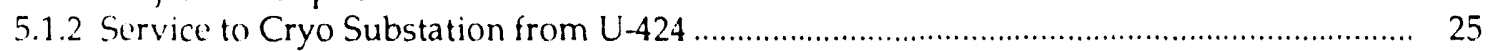

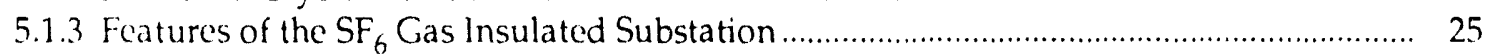

Project 5.2-Load Grid Switchgear Assembly Additions ................................................................. 29

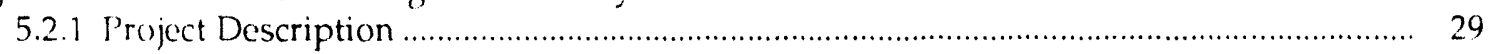


Project 5.3-13.8 kV Underground Duct Bank

and Manhole Distribution System ....

5.3.1 Project Description

Project 5.4 - 13.8 kV Express Feeders-Phase 1

5.4.1 Project Description

Project 5.5-13.8 kV Express Feeders-Phase 2 .

5.5.1 Project Description...

Project 5.6-Electrical Code Improvements ...

5.6.1 Project Description.

Project 5.7- Unreliable and Overstressed Low

Voltage Panelboard Replacement

5.7.1 Project Description

Project 5.8-Unreliable Low Voltage Feeder Replacement

5.8.1 Project Description

Project 5.9-Install SCADA System

5.9.1 Project Description

Project 5.10-Eliminate $12 \mathrm{kV}$ Distribution

5.10.1 Project Description

Project 5.11--Distribution Automation...

5.11.1 Project Description

Project 5.12-Voltage Conversion to $13.8 \mathrm{kV}$

5.12.1 Project Description

Appendix A-Studies and Reports

Identification of Previous Studies and Reports

31

31

33

33

34

34

35

35

35

35

36

36

36

36

38

38

38

38

38

38

39

39 


\section{List of Figures}

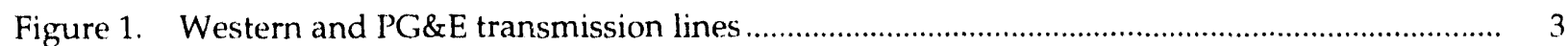

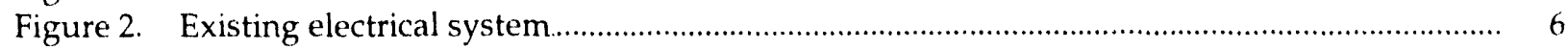

Figure 3. U-424 substation single-line diagram ............................................................................. 7

Figure 4. The $13.8 \mathrm{kV}$ underground duct bank system layout ....................................................... 10

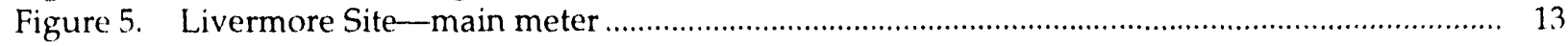

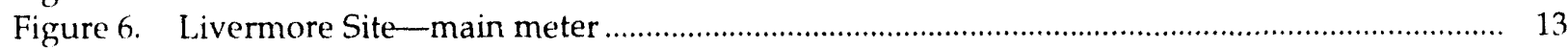

Figure 7. Livermore Site-main meter ............................................................................................. 14

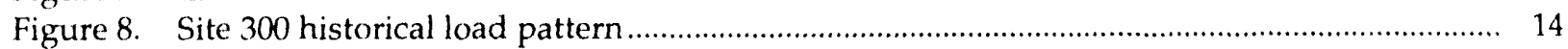

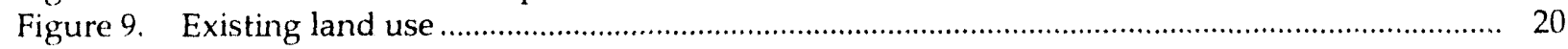

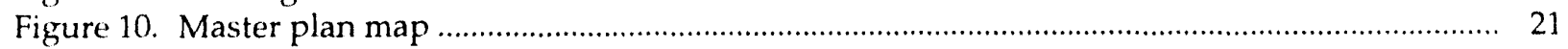

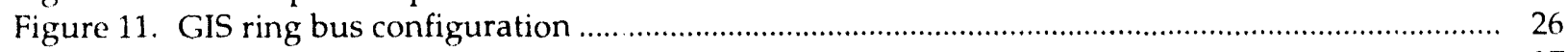

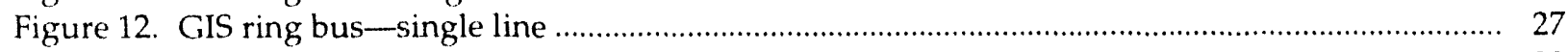

Figure 13. The $115 \mathrm{kV}$ overhead line to Cryo ................................................................................ 28

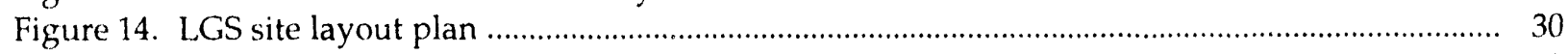

Figure 15. The $13.8 \mathrm{kV}$ underground duct bank system layout .......................................................... 32

Figure 16. Arrangement of the 13.8-kV express feeder-phase 1 ............................................................ 33

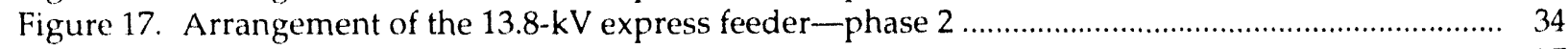

Figure 18. Arrangement of the SCADA concept ……..................................................................... 37

\section{List of Tables}

Table 1. Livermore Site-main meter historical consumption .............................................................. 12

Table 2. Annual energy and demand forecast summary ................................................................. 15

Table 3. Site 300 annual energy and demand forecast summary ......................................................... 16

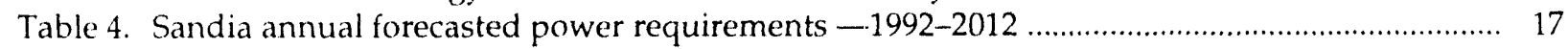

Table 5. Estimated requirements for future experimental loads ............................................................ 18

Table 6. Estimated increased power requirements ............................................................................. 18

Table 7. Proposed projects from the Site Development Plan ............................................................ 22 


\section{Abbreviations, Acronyms, and Definitions}

CRYO Cryogenic Substation-115/4.16 kV, 12.5 MVA substation used by the Magnetic Fusion Project.

EDS Electrical Distribution System-medium-voltage (12 or $13.8 \mathrm{kV})$ system used to distribute power from incoming utilities to buildings and substations.

EPSRU Electrical Power System Replacements and Upgrades-line item funding project for rebuilding the distribution system and correcting code violations.

GIS Gas Insulated Substation-115 kV-rated enclosure of gas insulated switchgear, metal enclosed and insulated with sulfa-hexafluoride $\left(\mathrm{SF}_{6}\right)$ gas.

LGS Load Grid Switchgear-medium-voltage $(13.8 \mathrm{kV})$ metal-clad switchgear enclosure, including a lineup of circuit breakers, metering, controls, and similar items.

Loop Style Normal utility distribution system allowing one circuit to enter and then leave a piece of Feed equipment, all the way through to the last piece of equipment, and then loop back to the source voltage supply.

SCADA Supervisory Control and Data Acquisition-remotely operated and monitored system used to control equipment on the Electric Distribution System.

U-424 Designation of the $115 \mathrm{kV}$ Switchyard immediately south of Building 424 . 


\section{General Information}

\subsection{Background Information- Livermore Site}

\subsubsection{General}

Lawrence Livermore National Laboratory (LLNL) is operated by the University of California under contract with the U.S. Department of Energy (DOE). Founded as a nuclear weapons design laboratory in 1952, LLNL has diversified into other fields. However, it remains a mission-oriented institution engaged in large-scale applied research progranis that require a multidiscipline approach. I LNL is recognized internationally as a binadly based research center.

\subsubsection{Location}

LLNL, Livernore Site, is located on an 821 -acre site at the eastern end of the Livermore Valley in southern Alameda County, California, about 50 miles southeast of San Francisco. Land uses in the surrounding valley are developirig urban, residential, light industrial, commercial, and residual agricultural land.

Sandia National Laboratories, I : vermore (SNLL), occupies land to the south of LLIVL, with a public road (East Avenue) separating the two DOE facilities.

LLNL Livermore and SNLL share facilities such as fire protection, a cafeteria, parking lot, and utilities. The surrounding undeveloped area consists of sparsely settled rangeland; the terrain is covered predominantly with grasses and chaparral. Some residential development has occurred west of the LLNL site.

\subsubsection{Physical Description}

Climate. The Livermore Valley has two distinct seasons, the rainy season and the dry season.

Precipitation. The rainfall, which normally averages 14 inches a year, occurs primarily between October and May. In the winter rainy season, the hills are bright green and there is an active runoff. Winter temperatures are mild. Frost usually occurs only at night, and temperatures below $20^{\circ} \mathrm{F}$ are rare.
Spring and fall are also mild with intermittent rain. Freezing is rare, and temperatures range between $60^{\circ} \mathrm{F}$ and $80^{\circ} \mathrm{F}$. Summers are hot and dry with temperatures often reaching $80^{\circ} \mathrm{F}$ to $100^{\circ} \mathrm{F}$. The landscape usually remains green until the rains stop in late April and May.

Prevailing Winds. Throughout the year, the valley is breezy and windless days are rare. Prevailing winds come from the west and southeast. The westerlies provide some relief in the hot summer by extending the moderating influences of the ocean inland.

Topography. Although LLNL Livermore Site is perceived as flat and level, the southeast corner is 100 feet higher than the northwest corner. The gently falling slope across this diagonal is a fairly consistent one and one-half percent (1-1/2\%). Three arroyos (water channels that dry up during the summer) intersect the site. Arroyo Seco flows west across the SNLL site south of the office and laboratory area. Arroyo Las Positas originates in the Livermore hills east of LLNL. It crosses Greenville Road and flows westerly into a drainage retention basin near the center of the site. This outlet constitutes the principal pathway for LLNL's surface drainage off site. The third drainage system is along Greenville Road and turns west along the North Buffer Zone, eventually exiting in the northwest corner of LLNL.

Subsurface Features. The LLNL and SNLL laboratories are located in the southeastern portion of the Livermore Valley, a topographic and structural depression cutting east-west across the Central California Diablo Range. Parts of the Livermore Valley are subject to ground motion from large seismic events on the San Andreas, Hayward, and Calaveras Faults, the major known active faults in the San Francisco Bay Area.

\subsubsection{Programs}

LLNL is engaged in large-scale applied research programs. The mission of LLNL is to be a national resource of scientific, technical, and engineering capability that especially focuses on national security. Major programs performed at the LLNL facility include but are not limited to the following: 
- Biotechnology.

- Energy.

- Lasers.

- Nonproliferation/ArmsControl/ International Securitv (NAI).

- Technology Transfer.

LLNL is functionally organized within a matrix framework. Each major program has an assigned staff that is supported by various technical disciplines (e.g., engineering, chemistry, computations, and physics). The support staffs are co-located at the program site because of the need to share major experimental facilities. Thus, programs provide eriough facility space to house their support personnel.

\subsubsection{Population}

Approximately 10,900 University, supplemental labor, and Federal Government Staff personnel are presently employed at LLNL Livermore Site and Site 300.

\subsubsection{Types of Facilities}

Since its formation in 1952, LLNL has acquired many facilities needed to carry out its research mission. Over the years, the gross area of facilities has continued to grow at varying rates and by mid- 1992 had reached approximately 5.5 million gross square feet.

The facility uses are:

- Office/drafting uses.

- Light laboratories/shops.

- Heavylaboratories.

- Miscellaneous.

Office/Drafting Uses. Office and drafting areas house about 75 percent of LLNL's staff and are the most densely populated of the four use types.

Light Laboratories/Shops. Light laboratories and shops comprise approximately 20 percent of LLNL facilities. The work environment is typified by smaller equipment and apparatus. Most light laboratories are involved in direct research, and the shops are primarily for research support of the overall laboratory efforts.

Heary Laboratories. These facilities are usually marked by high-bay construction, overhead cranes, and perhaps shielding. In most cases, heavy laboratory space is directly supported by adjacent light laboratory space.

Miscellane'ous. This category includes computer rooms, storage, and office support areas (such as conference rooms, auditoriums, and classrooms).

\subsection{History and Availability of Electric Utilities - Livermore Site}

The property now occupied by Lawrence Livermore National Laboratory (LLNL) was purchased by the Navy in March 1942 for construction of the Livermore Naval Air Station. The property was then transferred to the Atomic Energy Commission in 1951. The electric service at that time was provided by Pacific Gas and Electric Company (PG\&E) over a single $12 \mathrm{kV}$ distribution line.

The normal load at LLNL is presently served at $115 \mathrm{kV}$ from three $115 \mathrm{kV}$ lines. Two lines are supplied from PG\&E and the third from Western Area Power Administration (Western). Figure 1 shows the layout of the existing Western and PG\&E transmission lines.

PG\&E does have one $230 \mathrm{kV}$ line from their Tesla Substation to LLNL. This line is an express feed to the MFE Program and these facilities are not part of this Master Plan.

The PG\&E lines originate at the Tesla Substation on Patterson Pass Road, 10 miles east of LLNL. An additional $115 \mathrm{kV}$ electrical service is being supplied by Western over a new $230 \mathrm{kV}$ transmission line from Western's Tracy Substation, located 12 miles northeast of the laboratory. This $230 \mathrm{kV}$ transmission line, which terminates at the $230 / 115 / 13.8 \mathrm{kV}$ Western Livermore Substation (WLS), is owned by and was installed by Western.

WLS is located adjacent to the northeast corner of LLNL, and a temporary overhead $115 \mathrm{kV}$ line has been installed to connect WLS with the South Main Substation (U-424) inside the LLNL site. Future plans call for the existing $115 \mathrm{kV}$ overhead line to be reinstalled underground.

Since the installation of the supply line from Western, the PG\&E lines have been used as "hot standby." Upon completion of the new gasinsulated $115 \mathrm{kV}$ ring bus on the EPSRU project, the two utility systems, by contract, will be operated in parallel, greatly enhancing the electrical service reliability at LLNL.

Western will also provide $13.8 \mathrm{kV}$ service to approximately one-half of the Laboratory's load from its WLS. It is anticipated that the Western system would be capable of allowing its transformer to remain in operation via an interconnection with PG\&E so that any problems on the Western system, such as at the Tracy 


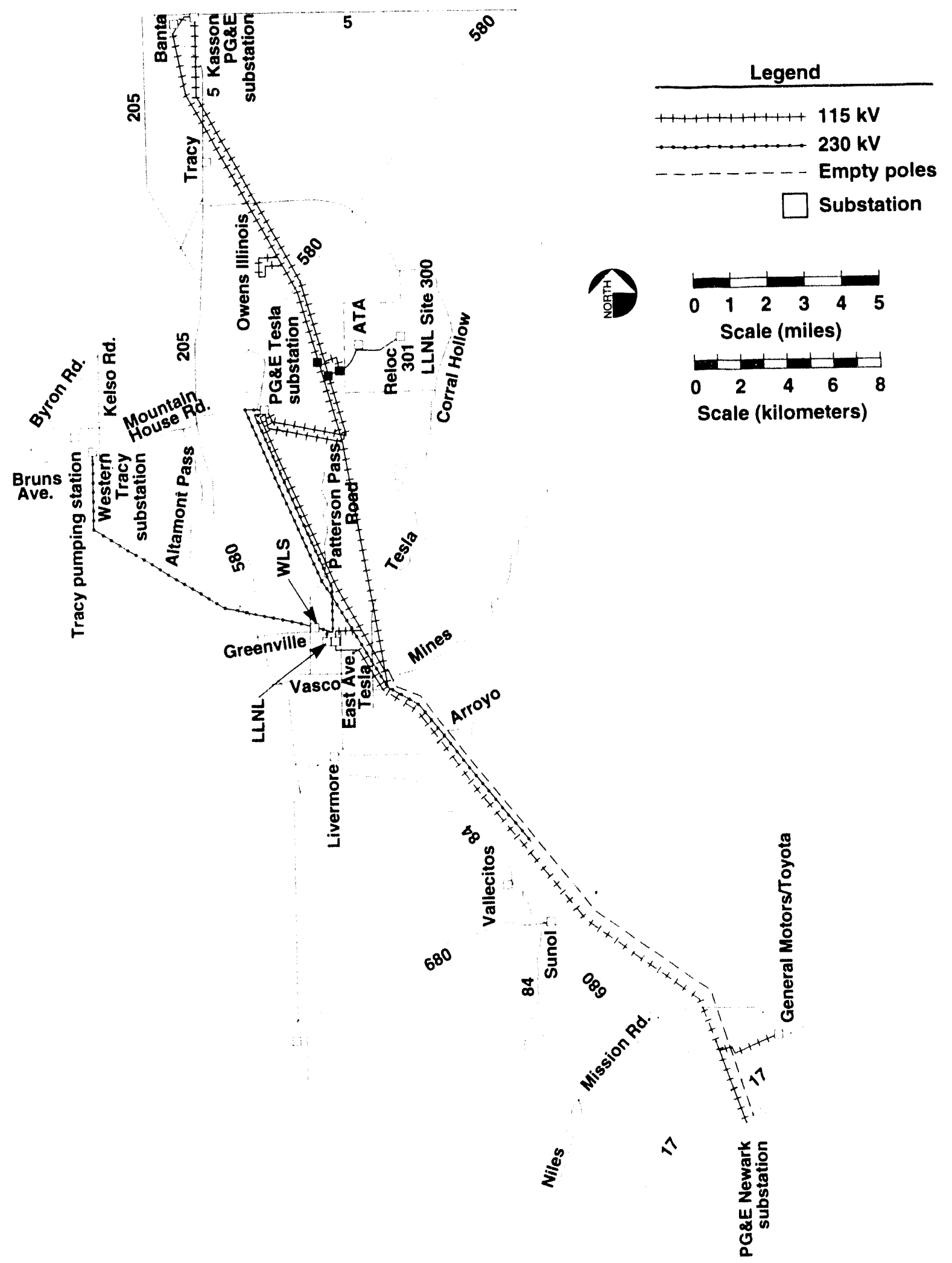

Fig. 1. Western and PG\&E transmission lines. 
Substation or between Tracy and the WLS, would have minimal effect on service to the Laboratory.

\subsection{Background Information-Site $\mathbf{3 0 0}$}

\subsubsection{General}

Site 300 is operated by the Lawrence Livermore National Laboratory as a high explosive test facility. Established in 1955 as a remote test facility to support the theoretical and development work at Livermore Site, Site 300 has expanded to include the Advanced Test Accel ator (ATA), Contained Firing Facilities, and the multibeam Fabry-Perot velocimeter.

\subsubsection{Location}

Site 300 is located on 6,893 acres in both Alameda and San Joaquin Counties about 17 miles southeast of Livermore, California. The surrounding area is sparsely populated, with the majority of land used for livestock ranching. Physics International and Stanford Research Institute (SRI) maintain explosive test facilities near the Site 300 property.

\subsubsection{Physical Description}

While the climate is similar to Livermore Site, the prevailing winds during the summer and early fall seasons are quite dynamic. The thermal inversion between the easterly San Joaquin Valley and the westerly Livermore Valley creates routine winds exceeding $65 \mathrm{mph}$. The terrain varies from rolling hills to steep canyons at elevations from 525 to 1070 feet above sea level.

\subsubsection{Types of Facilities}

A total of 341,427 square feet of space is occupied. Of this, oniy $4 \%$ are considered temporary facilities. All are in relatively good condition, but the General Services Area (GSA) has some overcrowding. The major problems with the infrastructures are the lack of an adequate and reliable water supply and the poor condition of the roads. Both conditions are being remedied. The overhead $12 \mathrm{kV}$ distribution is old and starting to deteriorate. The two substations are adequate to meet the currently forecasted site demands.

\subsection{History and Availability of Electric Utilities-Site $\mathbf{3 0 0}$}

One substation (T-301) serves the normal three-to-four $\mathrm{N}$ WW site load. The substation was installed in 1985 and is large enough to carry the site load for the foreseeable future. A second substation (T-525) serves the ATA facility. Built in 1981 for the program, it is now used basically to serve the in-house ATA lighting load. A $12 \mathrm{kV}$ tieline between the two substations is currently being installed to allow full transfer of load from one substation to the other for both emergency and maintenance situations.

Site 300 is currently served at $115 \mathrm{kV}$ from Pacific Gas and Electric Company's Tesla Substation. The line is tapped at two locations, one at each of the substations (T-301 and T-525). 


\section{Existing Conditions-Description and Operational Constraints of Existing Electric System}

\subsection{South Main Substation}

The South Main Substation (U-424) is located at the intersection of South Gate Drive and Outer Loop Road inside LLNL Livermore Site. The $115 \mathrm{kV}$ switchyard is north of the Outer Loop Road and south of Building 424. The building houses two $13.8 \mathrm{kV}$ switchgear assemblies, the $115 \mathrm{kV}$ controls, and the metering for both incoming power and feeder circuits to the area substations on the site. (See Figure 2).

The substation area is congested and the configuration and installation of the $115 \mathrm{kV}$ bus places limitations on maintenance and restricts flexibility of operation. To maintain or remove some of the existing equipment, it is necessary that portions of the substation be de-energized.

The $115 \mathrm{kV}$ switchyard at U-424 contains a $115 \mathrm{kV}$ bus network which provides the means for connecting to either $115 \mathrm{kV}$ transmission line through motor-operated switches. The station presently contains $115 \mathrm{kV}$ switches, including one that provides service to a remote $115 / 4.16 \mathrm{kV}$, 12.5/16.625 MVA substation located 400 feet northeast of U-424 and serves the Cryogenic (Cryo) Plant.

The two motor-operated line-disconnect switch.es cannot both be operated in the closed position for an extended period of time, since the station is not presently designed for parallel operation (See Figure 3).

If both lines are energized, load can be transferred without an interruption by closing the alternate switch and opening the preferred switch. The switches are also capable of deenergizing the normal $115 \mathrm{kV}$ line back to the Tesla Substation or WLS.

Additional equipment located in the switchyard includes $115 \mathrm{kV}$ metering, area lighting, and circuit breaker control relays in addition to conduit, cable, and other related electrical equipment required for operation of the substation electrical system. A $40 \mathrm{~kW}$ standby generator supplies backup power to the station service on loss of total power.

Transformer T-900 was installed in 1985, and the T-200 transformer went on-line in mid-1989.
An underrated $115 \mathrm{kV} \mathrm{SF}_{6}$ circuit switcher protects $\mathrm{T}-900$, while a properly rated $\mathrm{SF}_{6}$ circuit breaker protects T-200.

Located at the north side of U-424 is Building 424, which houses two $13.8 \mathrm{kV}$ switchgear assemblies equipped with vacuumtype circuit breakers. These switchgear assemblies are identified as T-200 and T-900, and they connect to the associated $115 / 13.8 \mathrm{kV} 60 / 80 / 100$ MVA transformer via bus ducts.

The function of the T-200 and T-900 transformers is to reduce the incoming voltage of the electric power from the $115 \mathrm{kV}$ transmission lines to the $13.8 \mathrm{kV}$ level for distribution to the various load centers on the site. These transformers are equipped with automatic load tap changers which operate to maintain the $13.8 \mathrm{kV}$ output voltage at a constant level as the load on the site varies. Each transformer is capable of delivering a maximum load of 100 MVA.

Both $13.8 \mathrm{kV}$ switchgear assemblies are similar in construction in that they are equipped with two separate main buses. Each bus is served by a $3000 \mathrm{~A}$ main circuit breaker which is connected to a corresponding $115 / 13.8 \mathrm{kV}$ transformer. Each bus in the T-200 switchgear is also connected to a corresponding bus in the T-900 switchgear via a $2000 \mathrm{~A}$ tie feeder. The T-200 switchgear assembly contains thirteen $1200 \mathrm{~A}$ feeder breakers and space for four additional $1200 \mathrm{~A}$ feeder breakers. The T-900 switchgear assembly is equipped with nine $1200 \mathrm{~A}$ feeder breakers. Two feeder positions are being used to feed the power factor correction equipment.

\subsection{The $13.8 \mathrm{kV}$ Distribution on Site}

Electric power is distributed on the site from the U-424 to the area substations by a $13.8 \mathrm{kV}$ resistance-grounded wye system. The majority of this power is delivered through underground conduits, with a small portion on overhead poles.

Figure 2 shows the layout of the existing $13.8 \mathrm{kV}$ electrical distribution system on site. 


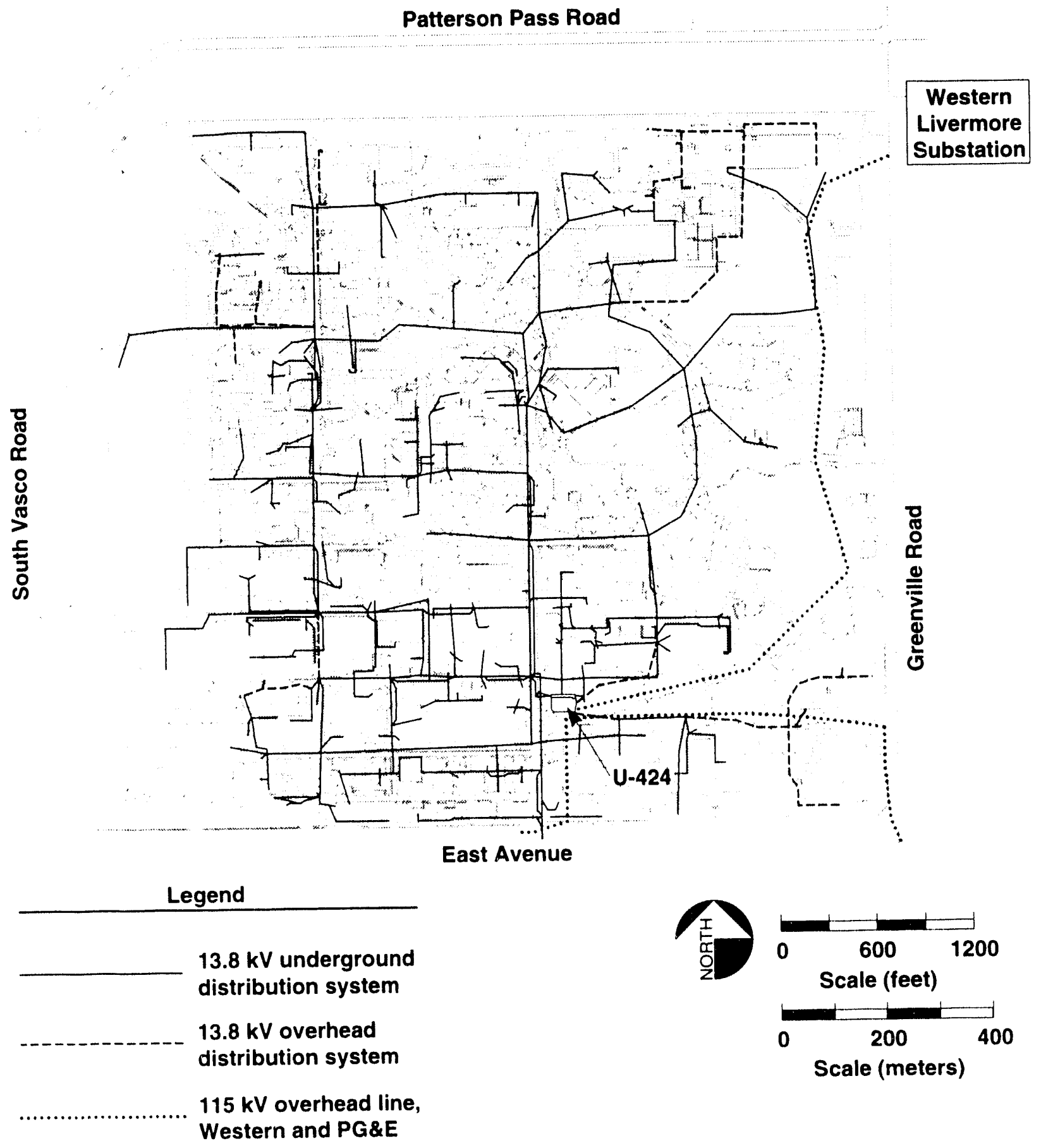

Fig. 2. Existing electrical system. 


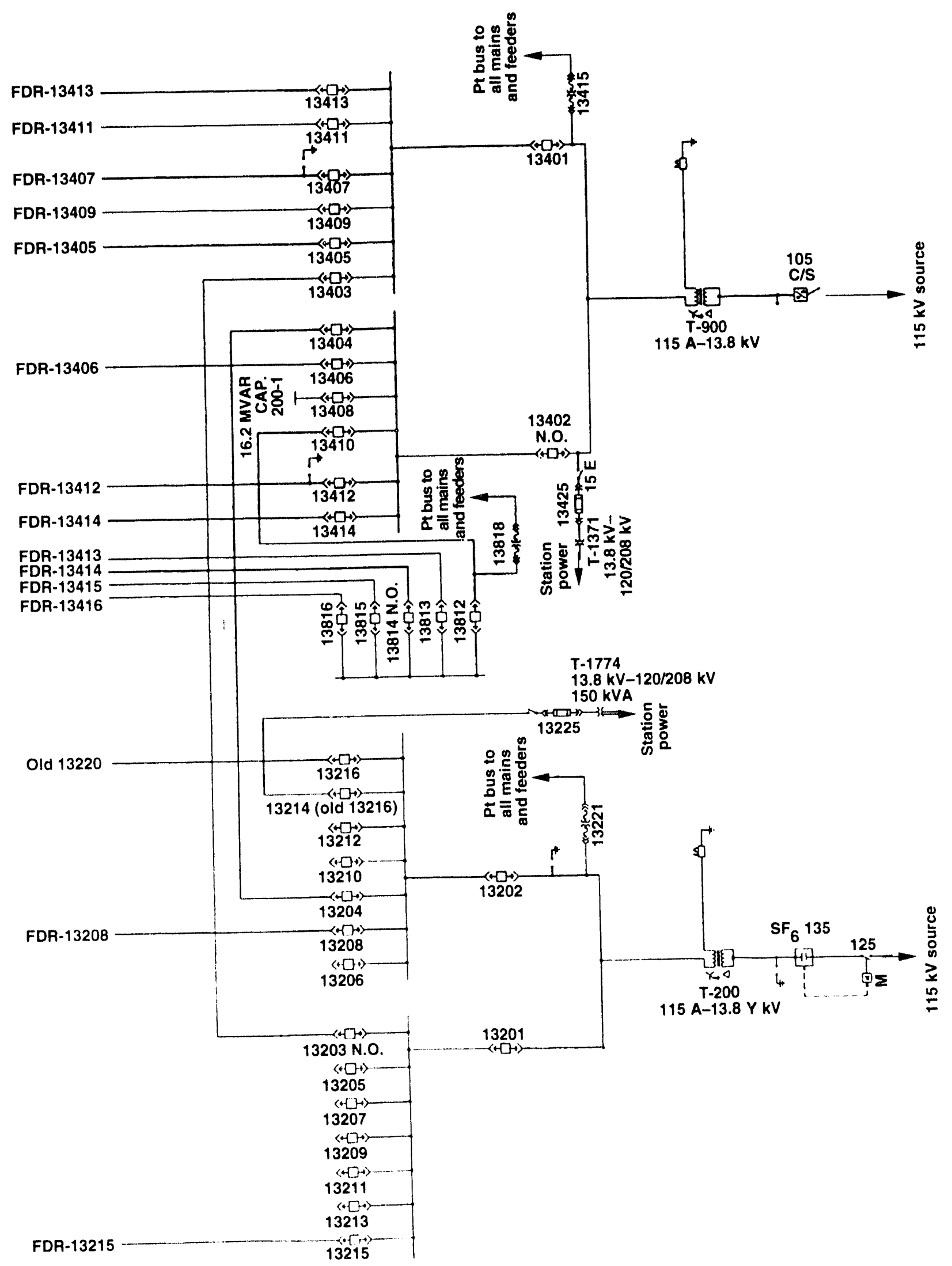

Fig. 3. U-424 substation single-line diagram. 
Each circuit of the existing underground electrical system between $\mathrm{U}-424$ and the area substations consists, in general, of three $500 \mathrm{KCM}$ cables installed in 4-inch conduits of transite or PVC pipe encased in concrete. In general, these conduits are located on the north and west side of roadways and buried approximately two feet below the surface.

Most existing cables are inadequate in size for carrying the forecasted loads. The size of conduits does not allow for the installation of additional cables or for replacing the existing cables with cables of sufficient size to supply the projected loads. The size of some of the existing manholes is also inadequate to permit the installation of additional cables. Some existing manholes do not have the space to meet the code requirements for bending and pulling the cables or the physical area to accommodate larger cables.

Some of the existing conductors making up the electrical distribution system have been installed over the past 20 years. Small segments, mostly in the northeast and southeast areas, are served from conductors installed on overhead poles. Much of both of these systems are no longer adequate to meet the load growth expected beyond the next five years.

Six fused area substations are presently located on the site. The locations of these are no longer at the load centers. They are supplied by a single circuit from the power source located at the U-424. This configuration does not provide for an alternate source of power for the stations in case of a cable failure.

The purpose of these area substations was to provide voltage regulation and switching control for the feeders which serve the building unit substations. Five of these area stations have fuses for circuit protection. This equipment is obsolete and cannot be depended upon to provide adequate service. The existing fuses do not provide adequate ground fault protection, nor do they have the capacity for proper coordination with the $13.8 \mathrm{kV}$ fuses located at the building unit substations or the relays at Building 424. The sixth area substation contains only switches, no fuses.
When the power distribution system at the laboratory was first developed, it was designed as a loop system which served the area substations. A loop system is compris ?d of two feeders of equal current carrying capability. Each feeder is able to carry the full assigned load, but is normally limited to $50 \%$ of its rated capacity. The open loop system will provide redundant service to each area substation which permits required maintenance and service to be performed with minimum or no downtime. The initial loop system concept has been compromised over the years by the addition of new loads. Two options are possible to resolve this condition: the existing loads must be redistributed to other feeders, thereby reducing the feeder load to the $50 \%$ criterion, or new cable must be installed to provide added capacity.

\subsection{The $12 \mathrm{kV}$ System}

The initial on-site distribution of power on the site was from a PG\&E overhead system operated at $12 \mathrm{kV}$. Over the years, almost all of this original system has been replaced. When the decision was made to replace the $12 \mathrm{kV}$ distribution system with a $13.8 \mathrm{kV}$ system, some of the transformers which reduced the $12 \mathrm{kV}$ primary voltage to the 480 volts used within the buildings had just been installed.

To eliminate the need of replacing these transformers, it was decided to install autotransformers to reduce the revised site standard voltage from $13.8 \mathrm{kV}$ to $12 \mathrm{kV}$. With such an arrangement, it was possible to avoid early replacement of some 35 transformers. Various General Plant Project (GPP) and Utility Restoration (UR) projects have removed two of the three autotransformers, replaced the building transformers, and changed over the surrounding area to $13.8 \mathrm{kV}$. Only one autotransformer, at substation No. 5, remains and is scheduled for removal in FY94. 


\section{Planning Analysis}

\subsection{Rationale for the Master Plan}

The rationale for the electric utility system master plan is based on achieving the service reliability required by DOE $6430.1 \mathrm{~A}$. Adequate system capacity, operating flexibility, and maintainability must be considered while providing for all forecasted loads. Also included are the long-term contractual arrangements with the bulk power suppliers, Pacific Gas \& Electric (PG\&E) and Western Area Power Administration (Western), to supply the forecasted loads and to operate their systems in parallel at U-424. The historical forecasted loads are shown in Tables 1 through 6 , and Figures 5 through 8.

The goal of the planning rationale will be accomplished in two phases. These consist of a short-term (five-year) plan and a long-range (five-to 20-year) plan.

The short-term, five-year plan will install $115 \mathrm{kV}$ facilities, allowing both bulk power suppliers to operate their systems in parallel at $\mathrm{U}-424$. This will eliminate power outages to LLNL created by outages to either of their lines. Six new relay-activated circuit breaker switchgear installations, with feeds from both Western Livermore Substation (WLS) and U-424, will be installed as shown in Figure 4. A new duct bank is also included for the express feeders to these new switchgear installations. The remaining $12 \mathrm{kV}$ distribution will be converted to the standard $13.8 \mathrm{kV}$ distribution voltage. The more serious code violations from the 1989 Kaiser Engineering "High Voltage Power Distribution System" report will be corrected.

The long-term (five- to 20-year plan) will achieve the following: (1) modify existing and install new distribution feeders to allow for "loop style" connections; (2) add additional 115/ $13.8 \mathrm{kV}$ substation capacity; (3) reduce system fault duty; (4) convert the remaining overhead distribution to underground lines; and (5) upgrade the SCADA system to better control the distribution system.

\subsection{The Five-Year Plan Includes the Following:}

\subsection{1 $\mathrm{SF}_{6}$ Gas-Insulated Substation (GIS)}

Replace the air-insulated $115 \mathrm{kV}$ substation bus at Building 424 with a GIS in a ring bus configuration. This will allow both serving utilities to operate in parallel, which will ensure that if either supply were lost, there would be no interruption of service to LLNL.

\subsubsection{Load Grid Switchgears}

Replace six area distribution centers with six Load Grid Switchgears (LGS) containing modern vacuum circuit breakers and associated protective relay devices. Each LGS assembly contains eight feeder outlets. These 48 feeder outlets will replace 15 existing feeder outlets at U-424. Each LGS will be supplied by express feeders from two locations: the WLS and U-424. Of the eight feeders at each LGS, four will be served from each substation (WLS and U-424). If either substation should fail, a "high speed transfer scheme" at each LGS will automatically transfer the load to the other substation. All interconnecting facilities will be sized to satisfactorily accommodate this transfer.

SCADA facilities will be installed on all LGS incoming and outgoing feeders. The master control room will be located in B-517 with future backup provided in U-424.

\subsubsection{Underground Duct Bank and Manhole System}

Each circuit of the existing underground electric system between the main substation and the area substations, in general, consists of three $500 \mathrm{KCM}$ cables installed in 4-inch conduits of transite pipe or PVC pipe encased in concrete. In general, these conduits are located on the north and west side of roadways and buried approximately two feet below the surface. No empty ducts remain, and each contains the 


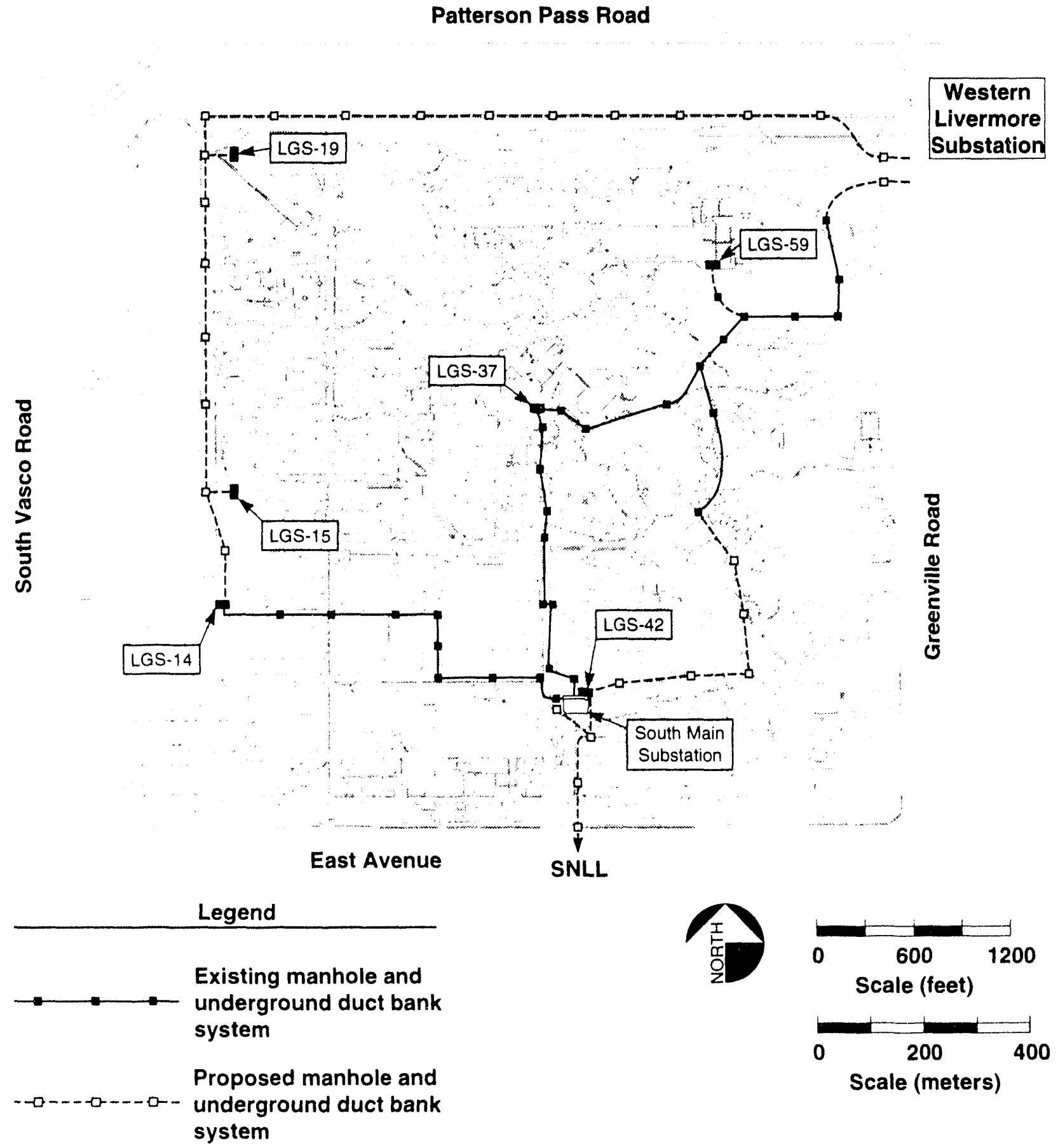

Fig. 4. The $13.8 \mathrm{kV}$ underground duct bank system layout. 
maximum number of conductors permitted by code. This constraint on size and fill does not allow for the installation of additional cables or for replacing the existing cables with cables large enough to supply the projected loads.

The sizes of most of the existing manholes are inadequate to permit the installation of additional cables. Most manholes do not have the space necessary to meet code requirements for bending and pulling the cables or the physical area to arcommodate cables of the size required to supply the forecasted load.

It is planned that a new underground duct bank and manhole system be installed from WLS and U-424 to the new LGSs for installation of the associated express feeders. The ducts in the multiduct bank system will be 6 -inch and the express feeders will generally be $750 \mathrm{KCM}$. Each LGS will be sized to serve an ultimate load of 25 MVA. The existing underground duct bank and manhole system will be retained wherever possible for use with the $13.8 \mathrm{kV}$ distribution systems which extend from the LGS assemblies to the unit substations or other load centers. The cables in the distribution system will be sized as required.

Figure 4 shows the route for the express duct bank.

\subsubsection{Electrical Code Corrections}

A comprehensive electrical survey of the medium voltage distribution has been completed by a group of qualified experts in medium/high voltage systems. The survey results revealed numerous safety code violations and good practice items that should be corrected. The most serious code violations have been corrected, and the balance are in the process of being completed.

\subsubsection{Replacement of Low Voltage Feeders and Panelboards}

The previously mentioned electrical survey also showed that of the LLNL buildings which are 25 years old or older, 21 had low voltage feeders requiring replacement due to cable deterioration. Increased fault duty has correspondingly increased personnel exposure and, in the case of failure of the feeder, may contribute dramatically to increased programmatic downtime. These feeders must be replaced.

\subsubsection{Unsafe Panelboards}

Of 535 panelboards surveyed, 251 require replacement because they are considered unsafe. Most fail to meet the criteria for their ability to interrupt the available short circuit current. If required to operate during a fault, the circuit breaker and panelboards could fail catastrophically requiring considerable time to repair and increased programmatic downtime.

\subsubsection{The $12 \mathrm{kV}$ and Overhead Conversion}

The $12 \mathrm{kV}$ distribution system on the west side of LLNL has reached the end of its life cycle. Most of the system has been converted to the LLNL standard voltage of $13.8 \mathrm{kV}$. To eliminate this radially fed $12 \mathrm{kV}$ system, this project will convert the $12 \mathrm{kV}$ to $13.8 \mathrm{kV}$ and relocate the $12 \mathrm{kV}$ overhead distribution in underground lines, allowing an alternate distribution feeder to be installed to feed these critical programmatic loads.

\subsection{The Long-Term (Five- to 20-Year) Plan Includes the Following:}

\subsubsection{The 13.8 kV Duct Bank and Distribution System}

Replace and upgrade the $13.8 \mathrm{kV}$ duct bank and distribution system to provide at least a loop style service to all existing building unit substations. Additional SCADA alarms, control metering, and fault monitoring systems and locations will be installed as necessary.

\subsubsection{The $115 \mathrm{kV}$ Substation and Transmission Loop}

When the LLNL load exceeds the firm substation capacity of $100 \mathrm{MVA}$, an additional $115 / 13.8 \mathrm{kV}$ substation transformer and associated transmission loop will be constructed. Additionally, the existing temporary overhead $115 \mathrm{kV}$ from WLS to U-424 will be placed underground.

\subsubsection{Upgrades to SCADA System}

Provide additions and upgrades to the SCADA system allowing for adequate control and monitoring of all distribution class equipment at LLNL. 


\subsubsection{Reduce System Fault Duty}

Since the substation transformers at U-424 were initially installed, the fault current capability of the utility supply has allowed the fault duty to increase to $32,000 \mathrm{~A}$. Electrical equipment manufacturers normally supply material with a maximum 25,000 A capacity, and some supply equipment to $40,000 \mathrm{~A}$, but at a significantly increased price.

To have properly rated equipment, 40,000 A-rated material must be installed. The alternative is to reduce the capacity to below the 25,000 A limit.

Industry-accepted practice is to install current-limiting reactors in the high voltage side of the substation transformers.

\subsubsection{Overhead Conversion}

Convert the northeast, northwest, and southeast overhead $13.8 \mathrm{kV}$ distribution systems to underground. This will dramatically improve the service reliability in these areas of the lab.

\subsubsection{Upgrade LGS Express Feeders}

Install new duct bank from U-424 to LGS-15 and add the third $750 \mathrm{KCM}$ cable per phase on all LCS express feeders to allow all future loads to be carried while maintaining voltage within LLNL approved standards.

\subsection{Fut ..e Energy Requirements}

The future demand (peak load) and energy use requirements are projected using three different scenarios. The historical load and energy usage is used as the base line for all three projected scenarios.

Table 1 and Figure 5 show the historical demands for the Livermore Site only. The Site 300 historical load is shown on Table 3. The Sandia historical loads are included in the Livermore Site data and are shown on Table 4. The Sandia forecasted load is included in Scenario \#2.

The three possible scenarios used for load projections are shown in Table 2 and are described in the following summaries:

Scenario \#1-This projected scenario represents the most likely case and is based on historical load growth. These values are to be used for power purchase contracts, as well as substation and transmission facilities planning.

Scenario \#2-In addition to Scenario \#1, this case includes Sandia projected growth plus the new, funded LLNL facilities. These values are to be used for capital investment planning for the sitewide distribution system. See Table 5.

Scenario \#3 - This projection includes Scenario \#2 plus all proposed new facilities and uncertain programmatic experimental loads. Data is presented to show a "very optimistic" view but is not being used for budgeting electrical projects. See Table 6 .

Table 1. Livermore Site-main meter.

Historical consumption

\begin{tabular}{|c|c|c|c|c|c|c|c|c|c|}
\hline $\begin{array}{l}\text { Fiscal } \\
\text { year }\end{array}$ & $\begin{array}{l}\text { Main EDS } \\
\text { max. } \\
\text { demand } \\
(M W)\end{array}$ & $\begin{array}{c}\text { Main EDS } \\
\text { total } \\
\text { energy } \\
\text { (MWh) }\end{array}$ & $\begin{array}{c}\text { Main EDS } \\
\text { increased } \\
\text { demand } \\
(\mathrm{MW})\end{array}$ & $\begin{array}{c}\text { Main EDS } \\
\text { increased } \\
\text { energy } \\
(M W h)\end{array}$ & $\begin{array}{l}\text { Fiscal } \\
\text { year }\end{array}$ & $\begin{array}{l}\text { Main EDS } \\
\text { max. } \\
\text { I demand } \\
(\mathrm{MW})\end{array}$ & $\begin{array}{c}\text { Main EDS } \\
\text { total } \\
\text { energy } \\
\text { (MWh) }\end{array}$ & $\begin{array}{c}\text { Main EDS } \\
\text { increased } \\
\text { demand } \\
(M W)\end{array}$ & $\begin{array}{c}\text { Main EDS } \\
\text { increased } \\
\text { energy } \\
\text { (MWh) }\end{array}$ \\
\hline 1970 & 26.7 & 159,811 & & & 1982 & 42.1 & 227,916 & $(-0.8)$ & 7,814 \\
\hline 1971 & 28.2 & 167,100 & 1.5 & 7,289 & 1983 & 46.7 & 245,403 & 4.6 & 17,487 \\
\hline 1972 & 29.2 & 177,800 & 1.0 & 10,700 & 1984 & 48.8 & 278,148 & 2.1 & 32,745 \\
\hline 1973 & 33.9 & 177,100 & 4.7 & $(-700)$ & 1985 & 52.0 & 294,506 & 3.2 & 16,358 \\
\hline 1974 & 30.9 & 178,983 & $(-3.0)$ & 1,883 & 1986 & 52.4 & 323,393 & 0.5 & 28,887 \\
\hline 1975 & 33.1 & 180,866 & 2.2 & 1,883 & 1987 & 56.8 & 329,086 & 4.4 & 5,693 \\
\hline 1976 & 38.5 & 193,635 & 5.4 & 12,768 & 1988 & 59.3 & 344,940 & 2.5 & 15,855 \\
\hline 1977 & 36.5 & 201,100 & $(-2.0)$ & 7,465 & 1989 & 61.1 & 355,225 & 1.8 & 10,285 \\
\hline 1978 & 40.0 & 216,476 & 3.5 & 15,376 & 1990 & 62.8 & 359,903 & 1.8 & 4,677 \\
\hline 1979 & 40.6 & 226,554 & 0.6 & 10,078 & 1991 & 61.5 & 359,275 & $(-1.4)$ & $(-3,628)$ \\
\hline 1980 & 41.2 & 221,482 & 0.6 & $(-5,072)$ & 1992 & 61.3 & 364,716 & $(-0.2)$ & 8,441 \\
\hline 1981 & 42.8 & 220,102 & 1.7 & $(-1,380)$ & \multicolumn{3}{|c|}{1993 Average: } & 1.6 & 9,459 \\
\hline
\end{tabular}




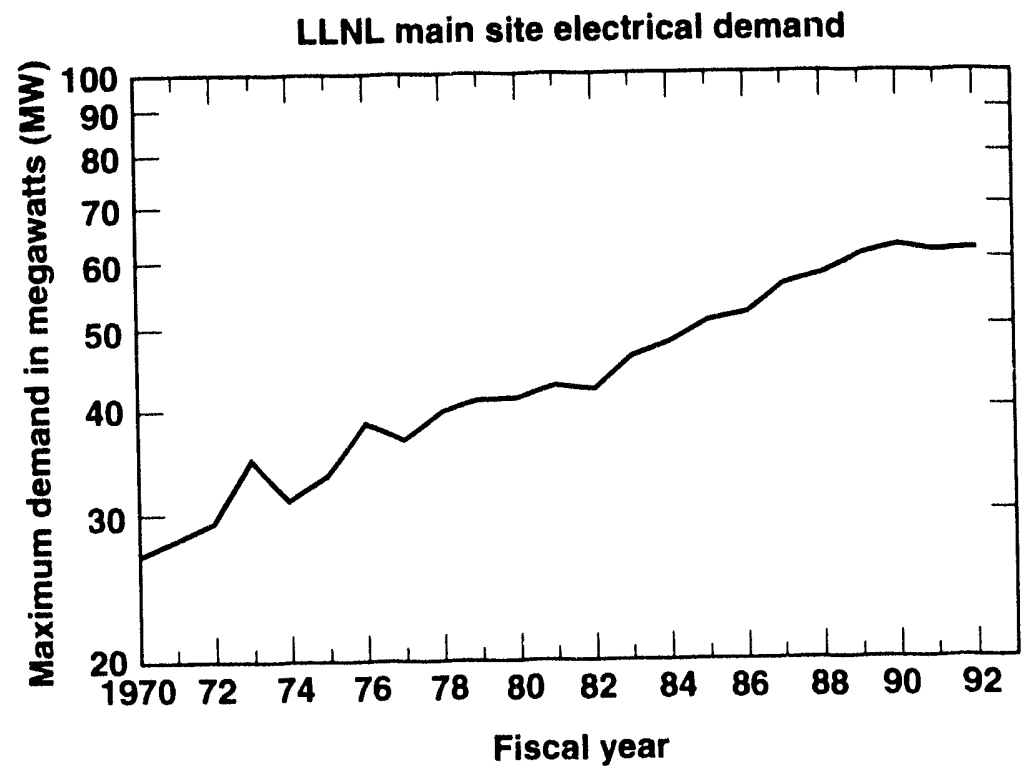

Fig. 5. Livernore Site-main meter.

Livermore main site forecast demand

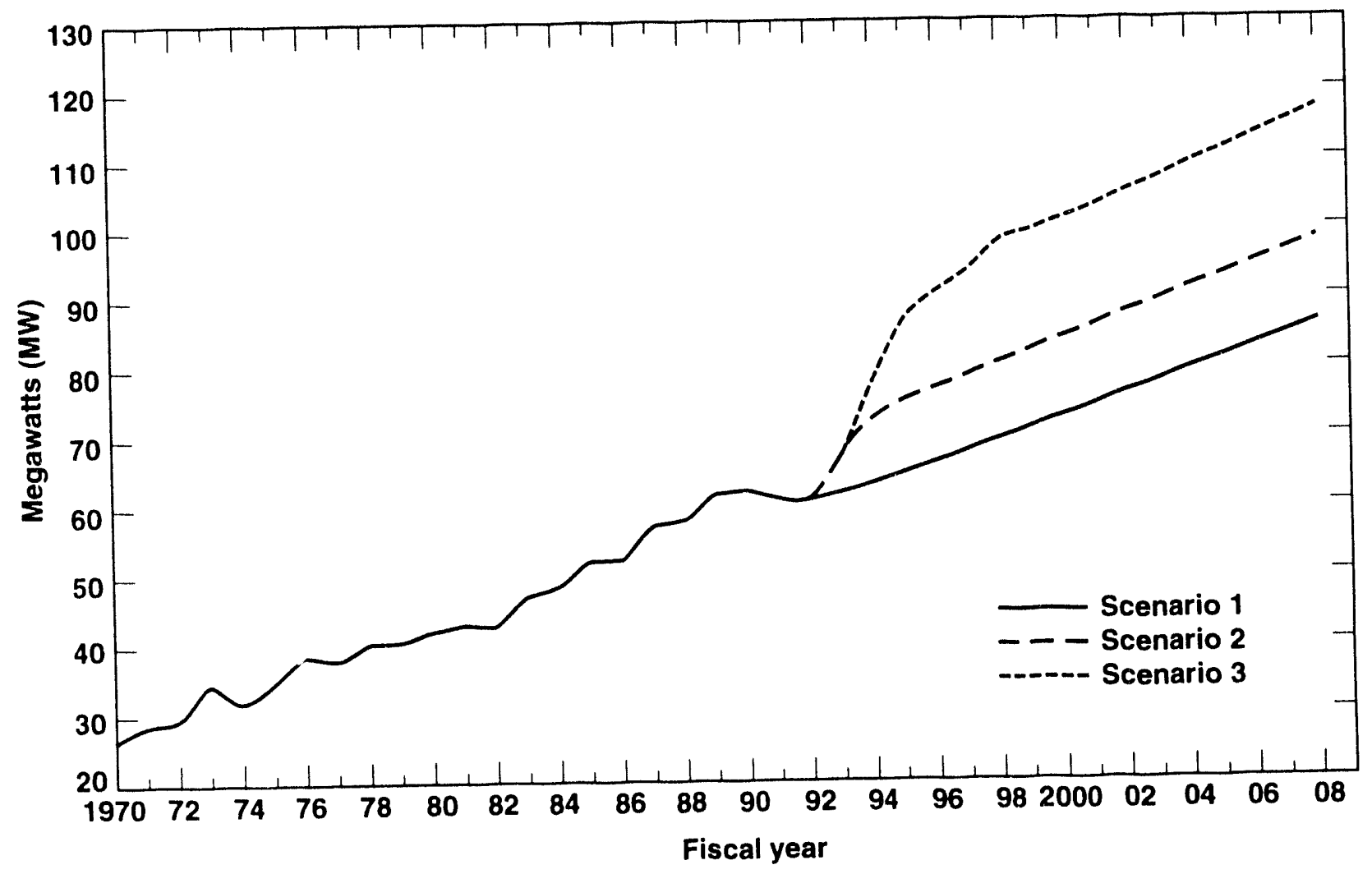

Fig. 6. Livermore Site-main meter. 
Livermore main EDS long-term forecast energy

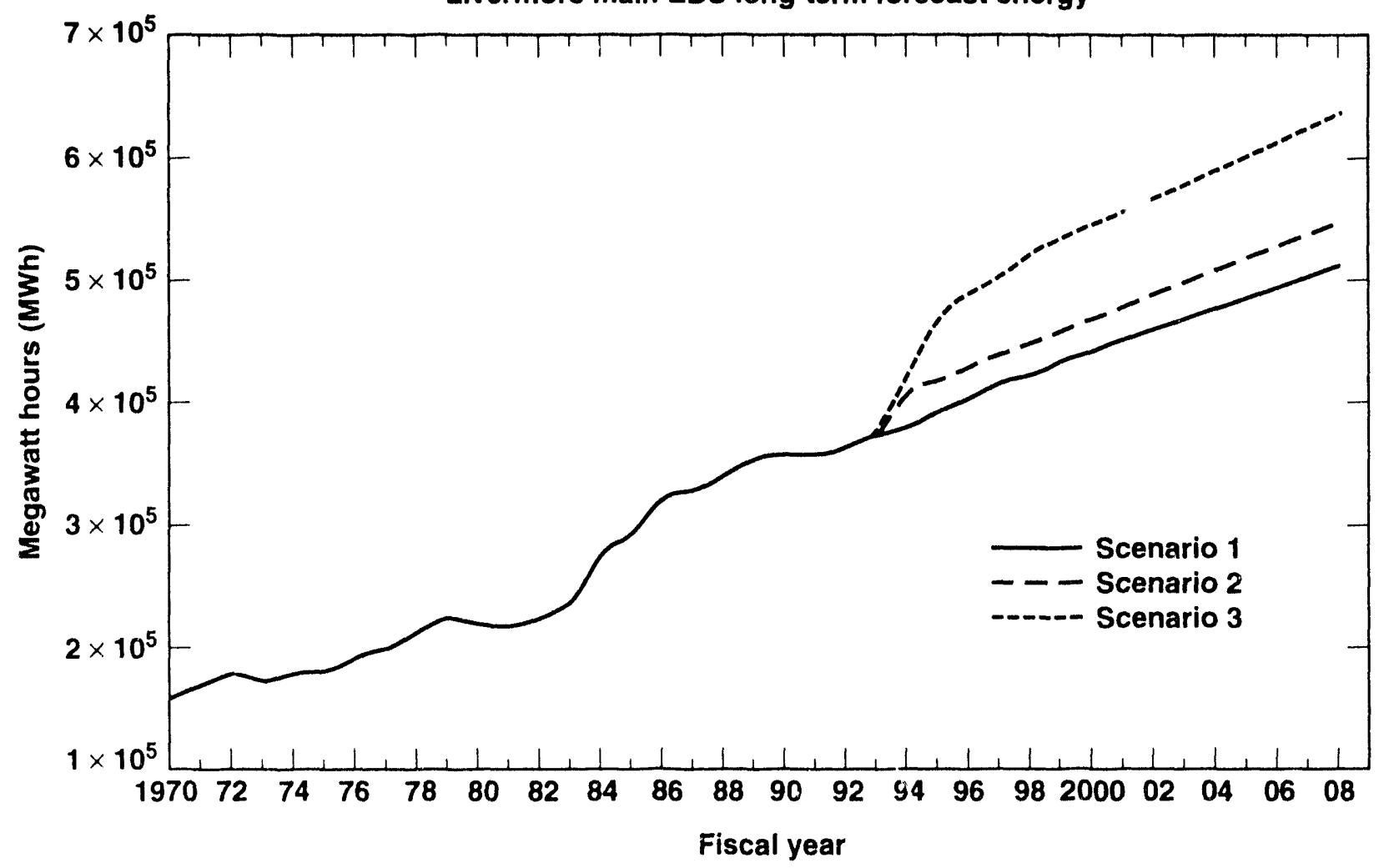

Fig. 7. Livermore Site-main meter.

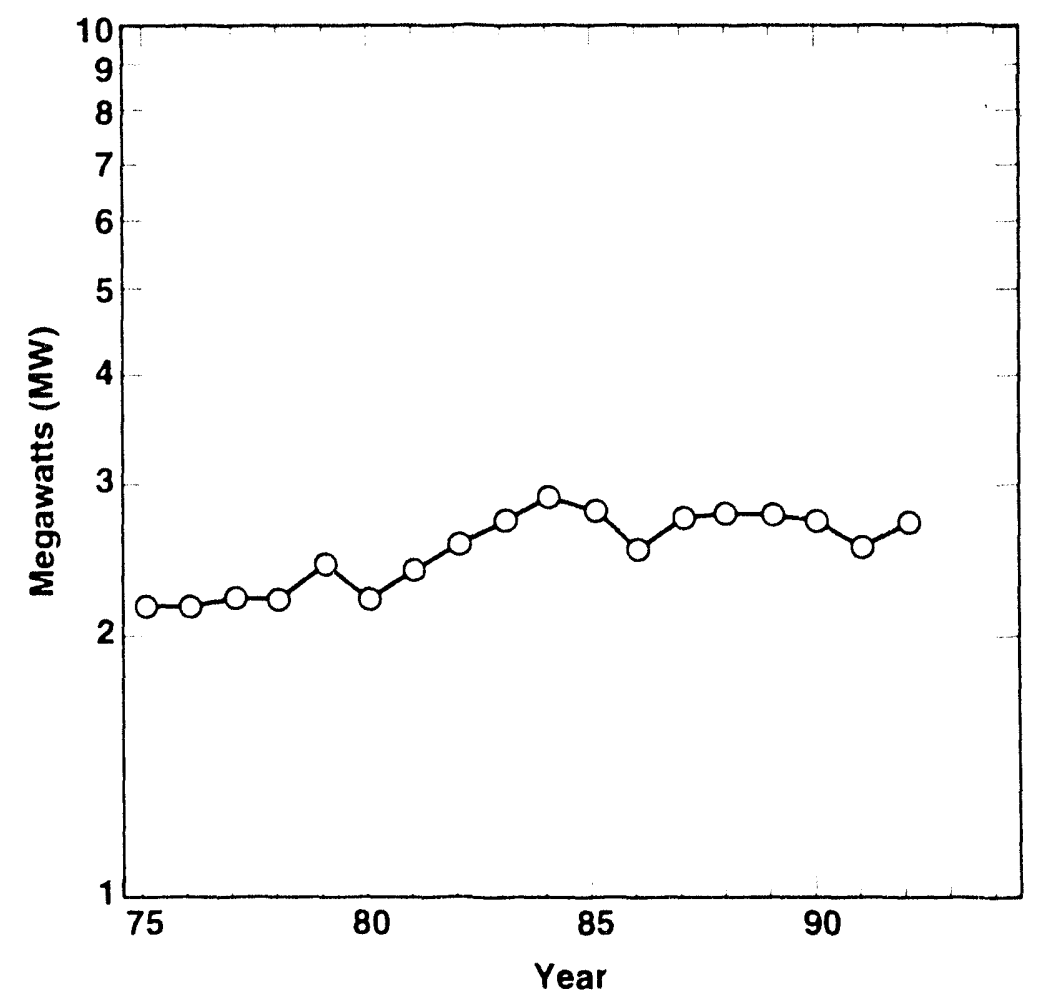

Fig. 8. Site 300 historical load pattern. 
Table 2. Annual energy and demand forecast summary.

\begin{tabular}{|c|c|c|c|c|c|c|}
\hline \multicolumn{3}{|c|}{$\begin{array}{c}\text { Scenario \#1 } \\
\text { Most likely case }\end{array}$} & \multicolumn{2}{|c|}{$\begin{array}{c}\text { Scenario \#2 } \\
\text { High but possible }\end{array}$} & \multicolumn{2}{|c|}{$\begin{array}{c}\text { Scenario \#3 } \\
\text { Very optimistic }\end{array}$} \\
\hline $\begin{array}{c}\text { Fiscal } \\
\text { year }\end{array}$ & $\begin{array}{c}\text { Maximum } \\
\text { demand } \\
\text { MW }\end{array}$ & $\begin{array}{c}\text { Total } \\
\text { energy } \\
\text { MWh }\end{array}$ & $\begin{array}{c}\text { Maximum } \\
\text { demand } \\
M W\end{array}$ & $\begin{array}{l}\text { Total } \\
\text { energy } \\
M W h\end{array}$ & $\begin{array}{l}\text { Maximum } \\
\text { demand } \\
\text { MW }\end{array}$ & $\begin{array}{c}\text { Total } \\
\text { energy } \\
\text { MWh }\end{array}$ \\
\hline $1992 *$ & 61.3 & 364,716 & 61.3 & 364,716 & 61.3 & 364,716 \\
\hline 1993 & 62.9 & 374,175 & 67.6 & 392,085 & 67.6 & 392,085 \\
\hline 1994 & 64.4 & 383,633 & 73.3 & 414,246 & 79.5 & 432,253 \\
\hline 1995 & 66.0 & 393,092 & 76.0 & 430,893 & 87.0 & 473,659 \\
\hline 1996 & 67.6 & 402,551 & 77.7 & 440,852 & 91.1 & 490,910 \\
\hline 1997 & 69.2 & 412,010 & 79.7 & 452,511 & 93.5 & 504,124 \\
\hline 1998 & 70.7 & 421,468 & 81.4 & 462,669 & 98.2 & 532,499 \\
\hline 1999 & 72.3 & 430,927 & 83.2 & 474,828 & 100.7 & 546,582 \\
\hline 2000 & 73.9 & 440,386 & 84.9 & 482,987 & 102.4 & 556,741 \\
\hline 2001 & 75.5 & 449,845 & 86.6 & 493,146 & 104.2 & 566,900 \\
\hline 2002 & 77.0 & 459,303 & 88.3 & 503,304 & 105.9 & 577,058 \\
\hline 2003 & 78.6 & 468,762 & 90.1 & 513,463 & 107.6 & 587,217 \\
\hline 2004 & 80.2 & 478,221 & 91.9 & 523,622 & 109.4 & 597,376 \\
\hline 2005 & 81.8 & 487,680 & 93.5 & 533,781 & 111.1 & 607,534 \\
\hline 2006 & 83.3 & 497,138 & 95.3 & 543,939 & 112.9 & 617,693 \\
\hline 2007 & 84.9 & 506,597 & 97.0 & 554,098 & 114.5 & 627,852 \\
\hline 2008 & 86.5 & 516,056 & 98.7 & 564,257 & 116.3 & 638,011 \\
\hline
\end{tabular}

"Actual maximum demand 
Table 3. Lawrence Livermore National Laboratory-Site 300 annual energy and demand forecast summary.

\begin{tabular}{|c|c|c|c|c|}
\hline $\begin{array}{l}\text { Fiscal } \\
\text { year }\end{array}$ & $\begin{array}{c}\text { Maximum } \\
\text { demand } \\
\text { MW }\end{array}$ & $\begin{array}{l}\text { Total } \\
\text { energy } \\
\text { MWh }\end{array}$ & $\begin{array}{l}\text { Delta } \\
\text { MW }\end{array}$ & $\begin{array}{c}\text { Increase } \\
\text { MWh }\end{array}$ \\
\hline $1975^{\star}$ & 2,151 & 27,906 & & \\
\hline $1976^{\star}$ & 2,130 & 32,096 & 0.8 & 4,190 \\
\hline $1977^{\star}$ & 2,186 & 35,400 & 0.8 & 3,304 \\
\hline 1978* & 2,188 & 39,780 & 0.5 & 4,380 \\
\hline $1979^{\star}$ & 2,396 & 38,200 & -0.6 & $(-1,580)$ \\
\hline 1980* & 2,190 & & & \\
\hline $1981^{\star}$ & 2,362 & 36,593 & -0.3 & $(-1,607)$ \\
\hline 1982* & 2,538 & 39,178 & 0.8 & 2,585 \\
\hline $1983^{* *}$ & & 50,400 & 2.1 & 11,223 \\
\hline 1984 & 2,882 & 51,200 & 0.2 & 800 \\
\hline 1985 & & 54,200 & 0.5 & 3,000 \\
\hline \multicolumn{5}{|l|}{1986} \\
\hline 1987 & & 54,780 & 0.1 & 500 \\
\hline 1988 & & 56,900 & 0.5 & 2,200 \\
\hline 1989 & & 57,600 & 0.1 & 700 \\
\hline 1990 & & 58,300 & 0.2 & 700 \\
\hline 1991 & & 59,000 & 0.1 & 700 \\
\hline \multicolumn{5}{|l|}{1992} \\
\hline 1993• & & 59,700 & 0.2 & 700 \\
\hline $1994^{\circ}$ & & 60,400 & 0.1 & 700 \\
\hline $1995^{\circ}$ & & 61,100 & 0.2 & 700 \\
\hline 1996• & & 61,800 & 0.2 & 700 \\
\hline $1997^{\circ}$ & & 62,500 & 0.1 & 700 \\
\hline \multicolumn{5}{|l|}{ 1998• } \\
\hline 1999• & & 63,200 & 0.2 & 700 \\
\hline 2000 & & 63,900 & 0.1 & 700 \\
\hline $2001 \bullet$ & & 64,600 & 0.2 & 700 \\
\hline $2002 \bullet$ & & 65,300 & 0.1 & 700 \\
\hline 2003 • & & 66,000 & 0.2 & 700 \\
\hline \multicolumn{5}{|l|}{2004 • } \\
\hline $2005 \bullet$ & & 66,700 & 0.1 & 700 \\
\hline 2006• & & 67,400 & 0.2 & 700 \\
\hline $2007 \bullet$ & & & & \\
\hline
\end{tabular}

"Estimated demand data used for FY75 through FY82

" No data available for FY83

-Averages were calculated for FY93 through FY07 using FY84-91 data 
Table 4. Sandia National Laboratory, Livermore Site-main meter. Annual forecasted power requirements-1992-2012.

\begin{tabular}{|c|c|c|c|c|}
\hline $\begin{array}{c}\text { Fiscal } \\
\text { year }\end{array}$ & $\begin{array}{c}\text { Maximum } \\
\text { demand } \\
\text { MW }\end{array}$ & $\begin{array}{c}\text { Total } \\
\text { energy } \\
\text { MWh }\end{array}$ & $\begin{array}{l}\text { Delta } \\
\text { MW }\end{array}$ & $\begin{array}{c}\text { Increase } \\
\text { MWh }\end{array}$ \\
\hline 1986 & 5.3 & 27,906 & & \\
\hline 1987 & 6.1 & 32,096 & 0.8 & 4,190 \\
\hline 1988 & 6.9 & 35,400 & 0.8 & 3,304 \\
\hline 1989 & 7.4 & 39,780 & 0.5 & 4,380 \\
\hline 1990 & 6.8 & 38,200 & -0.6 & $(-1,580)$ \\
\hline 1991 & 6.5 & 36,593 & -0.3 & $(-1,607)$ \\
\hline 1992 & 7.3 & 39,178 & 0.8 & 2,585 \\
\hline 1993 & 9.4 & 50,400 & 2.1 & 11,223 \\
\hline 1994 & 9.6 & 51,200 & 0.2 & 800 \\
\hline 1995 & 10.1 & 54,200 & 0.5 & 3,000 \\
\hline 1996 & 10.2 & 54,780 & 0.1 & 500 \\
\hline 1997 & 10.7 & 56,900 & 0.5 & 2,200 \\
\hline 1998 & 10.8 & 57,600 & 0.1 & 700 \\
\hline 1999 & 11.0 & 58,300 & 0.2 & 700 \\
\hline 2000 & 11.1 & 59,000 & 0.1 & 700 \\
\hline 2001 & 11.3 & 59,700 & 0.2 & 100 \\
\hline 2002 & 11.4 & 60,400 & 0.1 & 700 \\
\hline 2003 & 11.6 & 61,100 & 0.2 & 700 \\
\hline 2004 & 11.8 & 61,800 & 0.2 & 700 \\
\hline 2005 & 11.9 & 62,500 & 0.1 & 700 \\
\hline 2006 & 12.1 & 63,200 & 0.2 & 700 \\
\hline 2007 & 12.2 & 63,900 & 0.1 & 700 \\
\hline 2008 & 12.4 & 64,600 & 0.2 & 700 \\
\hline 2009 & 12.5 & 65,300 & 0.1 & 700 \\
\hline 2010 & 12.7 & 66,000 & 0.2 & 700 \\
\hline 2011 & 12.8 & 66,700 & 0.1 & 700 \\
\hline 2012 & 13.0 & 67,400 & 0.2 & 700 \\
\hline
\end{tabular}


Table 5. Estimated power requirements for possible future experimental loads.

\begin{tabular}{|c|c|c|c|c|c|c|c|c|c|c|c|}
\hline $\begin{array}{l}\text { Activ- } \\
\text { ation } \\
\text { date }\end{array}$ & $\begin{array}{c}\text { Fiscal } \\
\text { year }\end{array}$ & $\begin{array}{l}\text { Project } \\
\text { title }\end{array}$ & Description & $\begin{array}{l}\text { nded/ } \\
\text { posed }\end{array}$ & $\begin{array}{c}\text { Building } \\
\text { (see } \\
\text { legend) }\end{array}$ & $\begin{array}{c}\text { Gross } \\
\text { square } \\
\text { footage } \\
\left(\mathbf{k f t}^{2}\right)\end{array}$ & $\begin{array}{c}\text { kWh/ } \\
\text { gstl } \\
\text { month }\end{array}$ & $\begin{array}{l}\text { W/gstl } \\
\text { month }\end{array}$ & $\begin{array}{l}\text { MWh/ } \\
\text { month }\end{array}$ & $\begin{array}{c}\text { Annual } \\
\text { energy } \\
\text { usage } \\
\text { (MWh) }\end{array}$ & $\begin{array}{l}\text { Maximum } \\
\text { demand } \\
(\mathrm{kW})\end{array}$ \\
\hline $3 / 93$ & 1993 & NTTC & Nuclear Test Technical Complex & $\mathbf{F}$ & LLO & 172 & 6 & 15 & $1,114.6$ & $13,374.7$ & $2,580.0$ \\
\hline $10 / 93$ & 1994 & SAB & Security Administration Buliding & $\mathbf{F}$ & 0 & 36 & 2 & 6 & 77.8 & 933.1 & 216.0 \\
\hline $3 / 94$ & 1994 & DPRF & Defense Program & $\mathbf{F}$ & LLO & 194 & 7 & 17 & $1,424.7$ & $17,098.8$ & $3,298.0$ \\
\hline $10 / 93$ & 1994 & VISTA & $\begin{array}{l}\text { Verification Intelligence Special } \\
\text { Technical Assessment Center }\end{array}$ & $\mathbf{F}$ & LLUO & 47 & 4 & 10 & 201.7 & $2,420.9$ & 467.0 \\
\hline $10 / 94$ & 1995 & AERF & $\begin{array}{l}\text { Atmospheric Emergency } \\
\text { Response Facility }\end{array}$ & $\mathbf{F}$ & O/Comp & 40 & 9 & 15 & 349.1 & $4,188.7$ & 606.0 \\
\hline $10 / 96$ & 1997 & EPRF & $\begin{array}{l}\text { Environmental/Physics } \\
\text { Research Facility }\end{array}$ & $\mathbf{P}$ & LLO & 35 & 4 & 10 & 151.2 & $1,814.4$ & 350.0 \\
\hline $10 / 96$ & 1997 & DPLSF & $\begin{array}{l}\text { Defense Programs Laser Support } \\
\text { Facility }\end{array}$ & $\mathbf{P}$ & LUO & 90 & 3 & 7 & 272.2 & $3,265.9$ & 630.0 \\
\hline $10 / 96$ & 1997 & ESHF & $\begin{array}{l}\text { Environmental Safety and Health } \\
\text { Facility }\end{array}$ & $\mathbf{P}$ & LபO & 30 & 4 & 10 & 129.6 & $1,555.2$ & 300.0 \\
\hline $10 / 97$ & 1998 & GRF & Genomics Research Facility & $\mathbf{P}$ & LLO & 41 & 5 & 12 & 212.5 & $2,550.5$ & 492.0 \\
\hline $10 / 97$ & 1998 & LBC & Laboratory Business Center & $\mathbf{P}$ & 0 & 120 & 2 & 6 & 259.2 & $3,110.4$ & 720.0 \\
\hline $3 / 98$ & 1998 & DWTF & $\begin{array}{l}\text { Decontamination and Waste } \\
\text { Treatment Facility }\end{array}$ & $\mathbf{P}$ & ML & 96 & 11 & 19 & $1,046.2$ & $12,555.0$ & $1,816.4$ \\
\hline \multicolumn{12}{|l|}{ Legend } \\
\hline & & Medium & laboratory (ML) & & & & & & & & \\
\hline
\end{tabular}

Table 6. Estimated increased power requirements to accommodate possible future experimental loads.

\begin{tabular}{cllcr}
\hline Experiment & \multicolumn{1}{c}{ Description } & $\begin{array}{c}\text { Fiscal } \\
\text { year }\end{array}$ & $\begin{array}{c}\text { Increased } \\
\text { demand } \\
\text { MW }\end{array}$ & $\begin{array}{c}\text { Increased } \\
\text { energy } \\
\text { MWh }\end{array}$ \\
\hline NPBSE & Nuclear Particle Beam Space Experiment & 1994 & 3.2 & 9,335 \\
TMX & Intense Neutron Source Facility & 1994 & 3.0 & $\mathbf{8 , 6 7 2}$ \\
INTER & Superconducting Magnet Test Facility & 1995 & 3.0 & 17,345 \\
MCTF & Model Coil Test Facility & 1995 & 0.8 & 2,334 \\
STE & Steady State Super Conducting Tokomak Experiment & 1996 & $\underline{2.5}$ & $\underline{\mathbf{7 , 2 9 3}}$ \\
& & & $\mathbf{1 2 . 5}$ & $\mathbf{4 4 , 9 7 9}$ \\
\hline
\end{tabular}




\section{Long-Range Plan}

\subsection{Future Site Development}

This Master Plan is based on a long-range planning period from 1993 to 2013. The most recent information on expansion and growth at LLNL is contained in the 1993 Site Development Plan. According to that document, long-range (FY 2010) development is expected within the LLNL site along the newly constructed West Perimeter Road.

Three major areas identified for interior infill growth are as follows: (1) the Northeast Quadrant area between North Inner Loop and North Outer Loop Roads; (2) the Southeast Quadrant area bounded by Avenue $\mathrm{K}$ and South Outer Loop Road; and (3) the area west of Avenue A and north of Third Street. Each of these areas is shown on Figure 9.

During the planning period, population and building area are expected to increase moderately. The types of development in newly developed areas are expected to be similar to land uses in existing developed areas. These areas, which total approximately 38 acres, are expected to be filled in with facilities to a density comparable with existing developed areas. In addition to interior infill, a number of areas within the site have been identified for redevelopment.

The total potential expansion area for the long-range plan is 38 acres. A maximum of $45 \%$ of any open space may be considered available for the location of new facilities.

This corresponds to 750,000 square feet of potential building area. The current LLNL site area is 821 acres. Figure 10 shows future (longrange) expansion and redevelopment areas, and Table 7 shows major construction projects proposed for the next five years through FY98.

\subsection{Physical Improvements and Expansions Required}

The physical improvements, expansions, demolition, and replacement of the electric utility system will improve the appearance of the ite in the long term since most of the work will be placed underground or will replace existing equipment with new equipment at the approximate same general location and will be screened by landscaping as necessary. In the short term, there will be some unavoidable disruption for project construction and staging. All projects will be coordinated through the LLNL siting process.

It will not be necessary to expand the $115 \mathrm{kV}$ switchyarc' at the South Main Substation because a gas insulated ring bus substation (GIS) will be installed. The GIS requires less ground space than the existing air insulated bus system. A decorative wall around the South Main Substation will provide additional security as well as improve the overall appearance of the area.

The load grid switchgear (LGS) assemblies will consist of outdoor metal-clad switchgear installed near the loads. This minimizes expenditure, maximizes efficiency, and improves reliability.

A temporary $115 \mathrm{kV}$ tie line has been installed on wooden poles between the WLS and U-424 substations. The pole locations have been carefully selected to avoid interference with existing trees and preserve the appearance of the site. This line will be tapped to feed Cryo. Future plans call for this line to be reinstalled underground.

Several additional pad mounted sectionalizing switches will be installed throughout the site. Their installation will be in carefully selected locations.

The remainder of the electric system improvements and expansion will be underground or within buildings.

It is planned to replace the existing overhead pole lines in the northeast, northwest, and southeast corners of the site so that the entire site electric system will be underground. This will minimize the number of outages created by acts of nature (birds, lightning, wind, and similar items). 


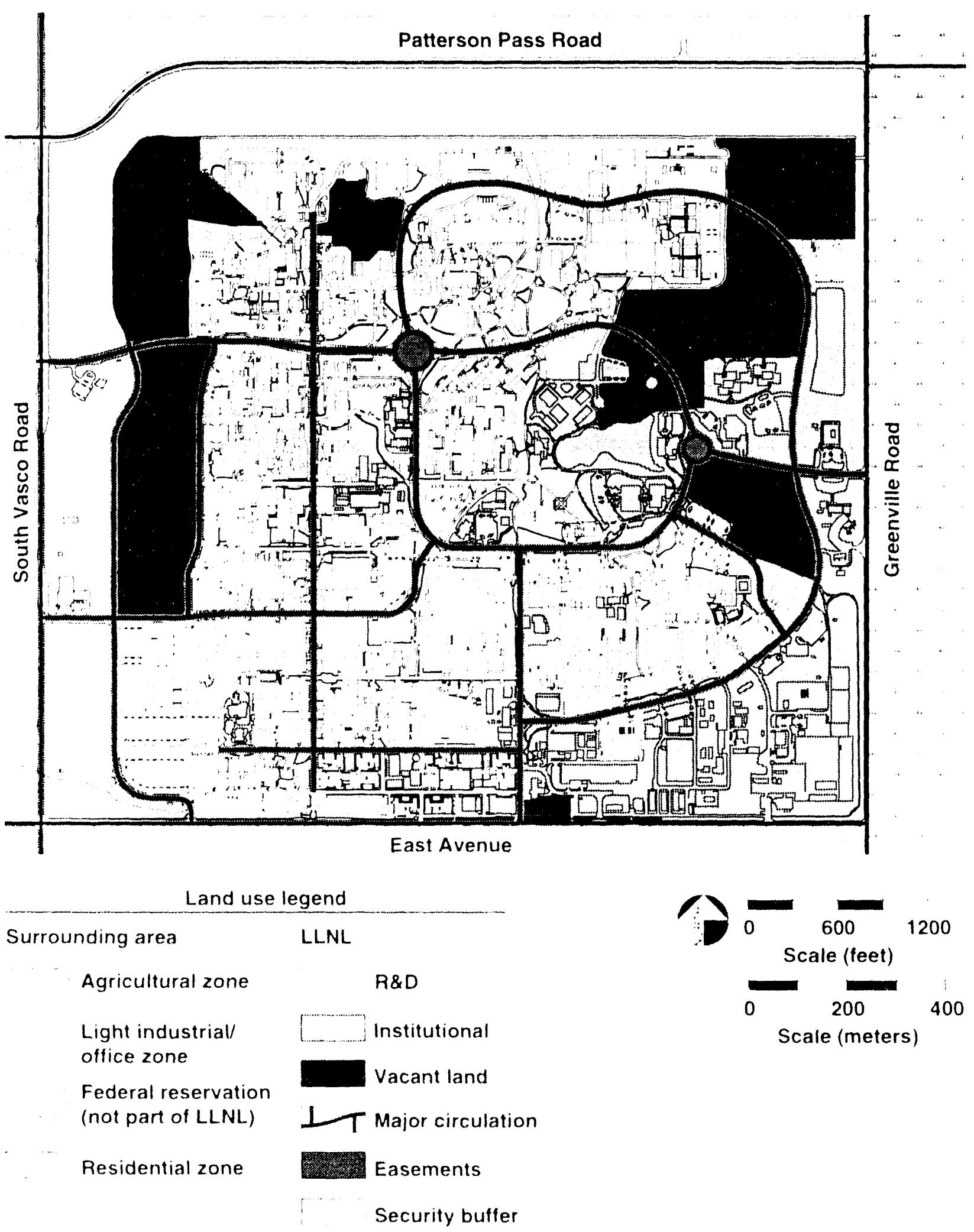

Iig. 4. Ixisting land use. 


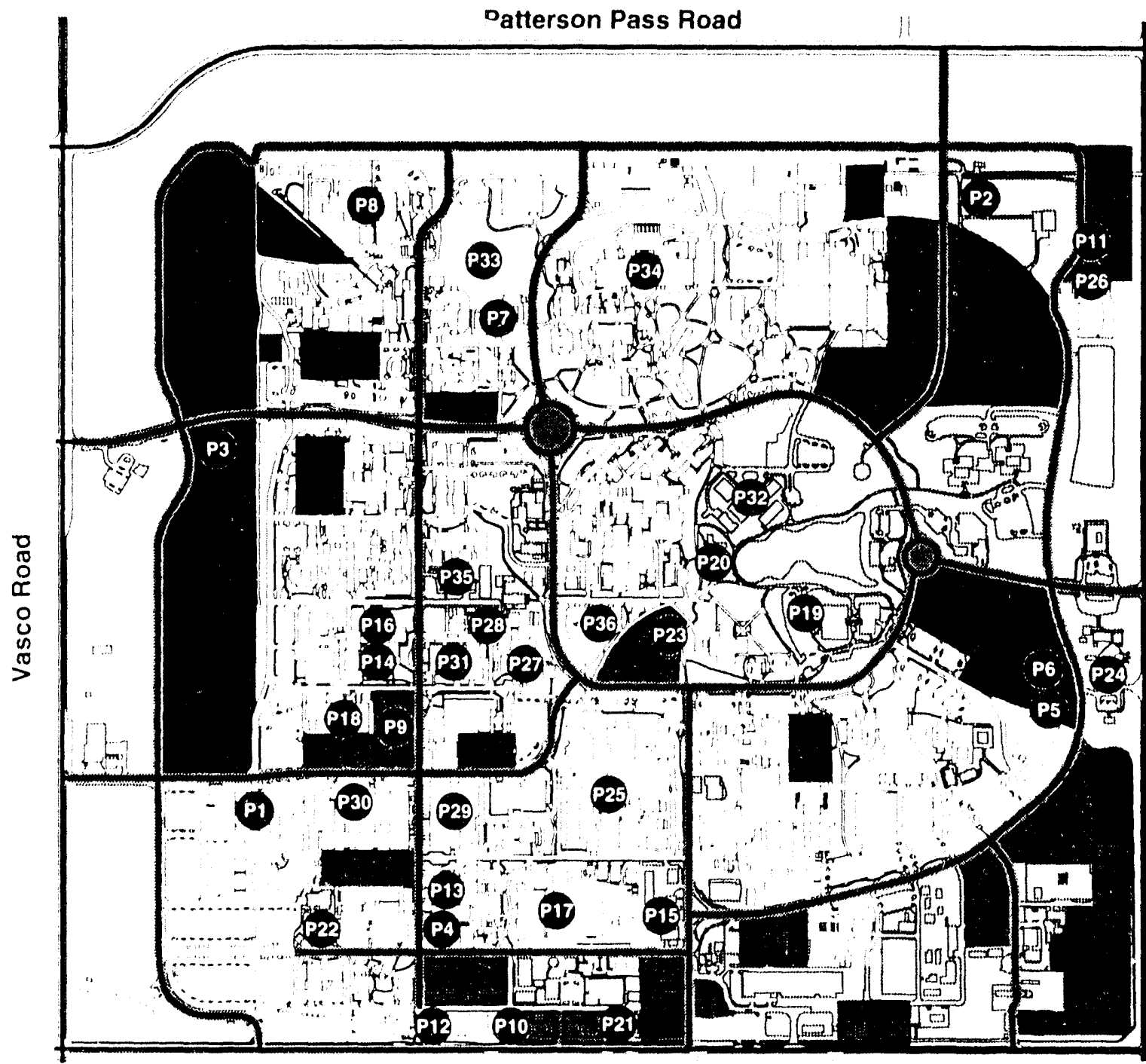

East Avenue

Land use legend

Construction projects

PN Proposed projects

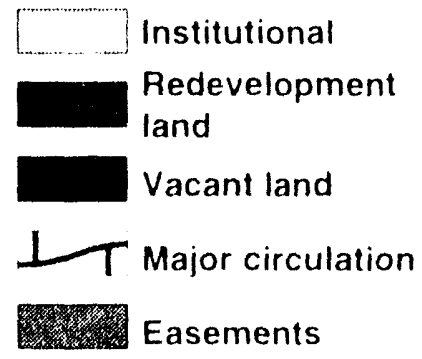

Security buffer

Fig. 10. Master plan map.

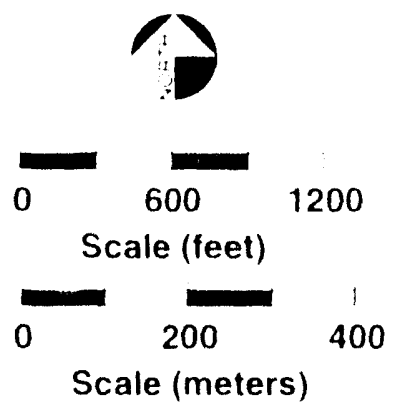


Table 7. Proposed projects from the LLNL Site Development Plan.

\begin{tabular}{|c|c|c|c|c|c|c|c|}
\hline $\begin{array}{l}\text { See } \\
\text { Appe }\end{array}$ & Project & $\begin{array}{l}\text { Fiscal } \\
\text { year }\end{array}$ & SEC & $\begin{array}{l}\text { See } \\
\text { Appe }\end{array}$ & Project & $\begin{array}{l}\text { Fiscal } \\
\text { year }\end{array}$ & TEC \\
\hline & Budgeted construction & & & & Civil maintenance-sitewide & 97 & 5.0 \\
\hline & Site 300 facilities revitalization project & 90 & 22.1 & & VHS unclassified data communication & 97 & 10.0 \\
\hline & Electrical power rep/upgrade I & 91 & 31.0 & & VHS classified data communication & 97 & 25.0 \\
\hline P1 & Defense Programs Research Facillty (DPRF) & 91 & 72.6 & P2O & Central cafeterla and conference center & s. & 6.5 \\
\hline P2 & Decontam.Maste Treatment Facility (DWTF) & 91 & 74.0 & P21 & South cafeteria & 97 & 5.5 \\
\hline & (Includes Mixed Waste Mgmt. Facility [MWMF]) & & & P22 & B-123 gen. upgrade (conf. center uparade) & 97 & 5.2 \\
\hline & Fiber optics comm. backbone & 91 & 4.6 & P23 & LI.IX admin housing & 97 & 3.2 \\
\hline & Infrastructure modernization & 92 & 13.8 & P24 & P bllc Affairs center & 97 & 6.0 \\
\hline & Sanitary sewer system rehabilitation & 92 & 13.5 & & Elec. power syst. replacement/upgrade \| & 97 & 40.0 \\
\hline & Energy conservation retrofits & 93 & 12.5 & P25 & Plutonium facillity upgrade & 97 & 27.3 \\
\hline & Tank upgrades project & 93 & 17.6 & P26 & Liv. Center for Adv. Manuf. and Productivity & 97 & 70.0 \\
\hline P3 & Atmospheric Emerg. Resp. Facllity (AERF) & 93 & 11.3 & P27 & Nano scale mat. facility & 97 & 10.1 \\
\hline & & & & P28 & Replace/refurbish Hazard Control Facility & 97 & 14.0 \\
\hline & Proposed construction & & & P29 & B231 Upgrade & 97 & 10.5 \\
\hline & Chlorofluorocarbon (CFC) Chiller Conversion & 95 & 16.0 & P30 & B131 general and environme & 97 & 15.0 \\
\hline P4 & Chemistry bldg. decon. and demo. (B-222) & 95 & 16.2 & P31 & B251 ventilation/seisn & 98 & 41.4 \\
\hline & al prop. Aoof replacements & 95 & 23.3 & P32 & Library fac & 98 & 1.9 \\
\hline & Road reconstru & 95 & 5.7 & & Backlo & 98 & 19.0 \\
\hline & Building drain & 95 & 10.8 & & $y$ prolects & 98 & 60.8 \\
\hline & Wast & 96 & 6.0 & & GB-02 Inertla & & \\
\hline P5 & Health Facillity (ES\&H) & 96 & 34.5 & P33 & Defense Programs la & 96 & 36.7 \\
\hline & & 96 & 14.0 & & & & \\
\hline & Addit & 96 & 10.0 & & Expe & & \\
\hline & $\begin{array}{l}\text { Plasma Physics research facillity } \\
\text { (Atomic Physics research facility) }\end{array}$ & 96 & 47.7 & & $\begin{array}{l}\text { National Ignition Facility pre-const. activities } \\
\text { (Nova Upgrade pre-construction activities) }\end{array}$ & 95 & 40.0 \\
\hline & Evacu & 96 & 13.0 & P34 & National Ignition Facility & 96 & 500.0 \\
\hline P6 & Lab b & 96 & 36.0 & & (Nova Upgrade) & & \\
\hline P7 & NW LC & 96 & 5.9 & & GC-01 Arms Control and Nonprolif & & \\
\hline P8 & B19 & 96 & 21.0 & P35 & Verif., Int'I Security, \& Tech. Analy. & Ctr. 95 & 21.7 \\
\hline P9 & Earth Scie & 96 & 32.0 & & Nonproliferation Annex (NPA) & 97 & 9.7 \\
\hline P10 & $213, \mathrm{~B} 319, \mathrm{~T} 2175, \mathrm{~T} 2177$ & 96 & 13.0 & & (Treaty Verification Center [TVC]) & & \\
\hline P11 & Transfer complex & 96 & 90.0 & & Biomedical research & & \\
\hline P12 & B212 replace lab & 96 & 63.5 & & KP.02 biological environm & & \\
\hline$P \div 3$ & Block 2 & 96 & 6.7 & P36 & Genomics research laboratory & 95 & 20.5 \\
\hline P14 & B151 & 97 & 15.0 & & Office admin/human re & & \\
\hline P15 & Hazards Co & 97 & 5.0 & & WB In-house energy management & & \\
\hline P16 & B151 plan and seismic upgrade & 97 & 18.0 & & In-house energy management & 94 & 18.5 \\
\hline & Upgrade s & 97 & 5.5 & & Site 300 experimental test site information & & \\
\hline$P 17$ & B321 general and environmental upgrade & 97 & 20.0 & & Contained firing facility & 94 & 36.9 \\
\hline & Fire safet & 97 & 5.1 & & te storage facility & 95 & 1.6 \\
\hline P18 & B141 general upgrade & 97 & 5.1 & & I facllity & 95 & 11.0 \\
\hline & lon-flooring & 97 & 12.0 & & d medical facillity & 95 & 3.8 \\
\hline P19 & B551 $W$ addition for TID & 97 & 8.0 & & Flash $x-$ & 97 & 27.8 \\
\hline & Bullding electrical systems code up!jrade & 97 & 29.4 & & Site facillties revitalization II & 97 & 28.1 \\
\hline & Backlog reduction-painting & 97 & 9.0 & & $\begin{array}{l}\text { HE machining facility } \\
\text { (See separate Site } 300 \text { development plan) }\end{array}$ & 98 & 16.7 \\
\hline
\end{tabular}




\subsection{Environmental and Safety Adjustments}

\subsubsection{Environmental Assessment}

An Environmental Assessment (EA) has been completed by LLNL, and a Finding of No Significant Impact (FONSI) has been issued for the proposed projects.

Short-term environmental impacts are likely to occur as a result of on-site construction activities. These impacts include dust (evacuation and replacement of soils), noise (heavy equipment operations and general construction activities), disposal of construction and demolition debris, and traffic disruptions near construction areas. Subsequent operations within the electrical distribution system will remain essentially unchanged.

The physical locations of the $115 \mathrm{kV}$ transmission lines, LCS switchgear, and $13.8 \mathrm{kV}$ underground distribution system have been coordinated with existing buildings, roads, and equipment and will be consistent with future plant planning as described in the LLNL Site Development I'lan.

Nocnvironmental impacts, except those result ing from normal construction activities will occur.

Project-specific activities will include the following:

- Soil sampling prior to excavation.

- Appropriate disposal of soil samples and excavation.
- Testing and safe disposal of removed equipment, including insulating oil.

- Compliance with the Bay Area Air Quality Management District reporting requirements if asbestos is encountered in any of the areas where demolition is to be performed.

Asbestos is not known to exist in any areas planned in this project.

\subsubsection{Safety Assessment}

A safety assessment for each project will be prepared, or at least an exemption will be sought. The design, construction, and operation of the facilities will comply with DOE, federal, and state regulations and other application codes and standards pertaining to health, safety, and fire protection.

All electric construction will be performed in strict compliance with and conformance to DOE orders, Federal OSHA, California OSHA, National Electrical Code, National Electrical Safety Code, California Public Utilities Commission General Orders GO-95 and GO-128, and LLNL Facilities Standards.

Deteriorated equipment replacement and code complance will result in a safer, as well as a more reliable system for the operating personnel and users. Seismic design shall be in accordance with LLNL and industry standards. 


\section{Five-Year Plan Projects}

\section{List of Projects (Summary)}

Project Description

5.1 $115 \mathrm{kV}$ South Main Substation (U-424)

Replace air insulated switchgear with $\mathrm{SF}_{6}$ gas insulated switchgear.

5.2 Load Grid Switchgear (LGS) assembly additions

Add five assemblies with vacuum breakers to replace six area witching stations with fuse protection.

5.3 $\quad 13.8 \mathrm{kV}$ duct bank and manhole distribution system Add duct bank from U-424 and WLS to each LGS.

Scheduled Estimated

Completion

FY94

FY95

$\$ 16,500$

FY95 (included with 5.2)

FY95 (included with 5.2)

FY95 (included with 5.2)

FY95

$\$ 4,400$

5.6 Electrical code improvements

Eliminate code violations in the medium- and high-voltage

electrical system.

5.7 Un reliable and overstressed low voltage panelboard replacement

FY95

$\$ 3,100$

Replace 251 of 535 surveyed panelboards, all of which contain

NEC code violations.

5.8 Unreliable low voltage feeder replacement

FY95

$\$ 4,000$

Replace deteriorated feeder wire in 21 buildings to

upgrade reliabiity.

5.9 Install SCADA system

Install supervisory control data and acquisition equipment

for the distribution system.

5.10 Eliminate $12 \mathrm{kV}$ overhead distribution

Install remaining $12 \mathrm{kV}$ underground.

5.11 Distribution automation

Add motor operators and SCADA controls to sectionalizing switches.

FY94

$\$ 1,000$

FY93

$\$ 940$

5.12 Voltage conversion to $13.8 \mathrm{kV}$

FY94

$\$ 1,100$
FY96

$\$ 800$ 


\section{Project 5.1-115 kV South Main Substation (U-424)}

\subsubsection{Project Description}

This project provides for replacing the existing South Main Substation (U-424) $115 \mathrm{kV}$ system with a new $115 \mathrm{kV}$ gas insulated substation (GIS) havi ig a ring bus configuration as shown on Figures 11 and 12 . The substation will have an incoming $115 \mathrm{kV}$ transmission line from the PCi\&E Tesla substation and a $115 \mathrm{kV}$ transmission line from the Western Livermore Substation (WLS). It can be constructed within the houndaries of the existing substation.

The existing $U-424$ is 40 years old, and the existing $115 \mathrm{kV}$ bus structure contains two motorized switches which can connect or transfer the main buses to either of the incoming $115 \mathrm{kV}$ transmission lines. There are several limitations to the existing bus structure arrangement. The circuit switchers installed in the bus structure are not rated to interrupt the available fault current from the utilities; the bus configuration does not provide the required flexibility to fully utilize the services from PCi\&E and Western; the existing configuration does not provide adequate clearances or access for required maintenance.

Replacement of the $115 \mathrm{kV}$ bus structure and associated equipment will correct the cited deficiencies, provide circuit breakers of sufficient interrupting capacity and provide proper clearances for maintenance and equipment replacement.

The U-424 Replacement Project is a vital element in the Master Ilan because it facilitates the parallel operation of Western and PG\&E sources of supply to the site.

The WLS and U-424 substations can be operated separately or in parallel and thereby permit serving the load grid switchgear assemblies, unit substations, and other load centers on the site from either or both substations with a mmimum of service interruption, thereby groatly incroasing reliability.

\subsubsection{Service to Cryo Substation from U-424}

The Cryogenic (Cryo) Substation is presently served from the $115 \mathrm{kV}$ hus in $\mathrm{U}-424$ through the dedicated 12.5 MVA, $115 / 4.16 \mathrm{kV}$ transformer. (See Figure 13.)

Cryosubstation will be removed from service in early 1944.

\subsubsection{Features of the $\mathrm{SF}_{6}$ Gas Insulated Substation}

The general ability of sulfa-hexafluoride (SF ${ }_{6}$ ) gas makes reductions in the size of substations. Three-dimensional configuration of the equipment, as well as the relationship with the transmission system and other equipment connected to it, provides a compact installation which requires only $1 / 10$ th to $1 / 20$ th of the ground space needed for a conventional type of air insulated substation.

The energized equipment is enclosed in a grounded metal structure, which minimizes the danger of electric shock. Furthermore, since SF is non-flammable, fire danger is eliminated, greatly improving safety. This makes it an ideal choice for installation in areas where space is at a premium.

The completely sealed equipment is unaffected by lightning or other weather conditions, or by corrosion caused by the environment. In the event of internal failure, the gas chambers are compartmentalized for each component, thus preventing damage from spreading and thereby increasing reliability.

The compact equipment reduces the space needed for the substation, thereby producing savings in land costs. In addition, maintenance costs will be dramatically less because all insulators are intermal and do not require cleaning.

Insulators and contactors are placed in highly stable $S F$, gas, which provides little deterioration or damage, and maintenance is minimized for the husbar or disconnecting switches. Circuit breakers require an internal inspection only on five-year or longer intervals.

The substation can be made compact, simplifying the work of constructing foundations and erecting support girders. Design and execution of the work is also simplified, and erection time is greatly reduced. Complete sealing of the circuit breakers and overall switching equipment eliminates problems of noise and radio interference.

This project will cost $\$ 5.2$ million and is funded by the EISTU line item. 

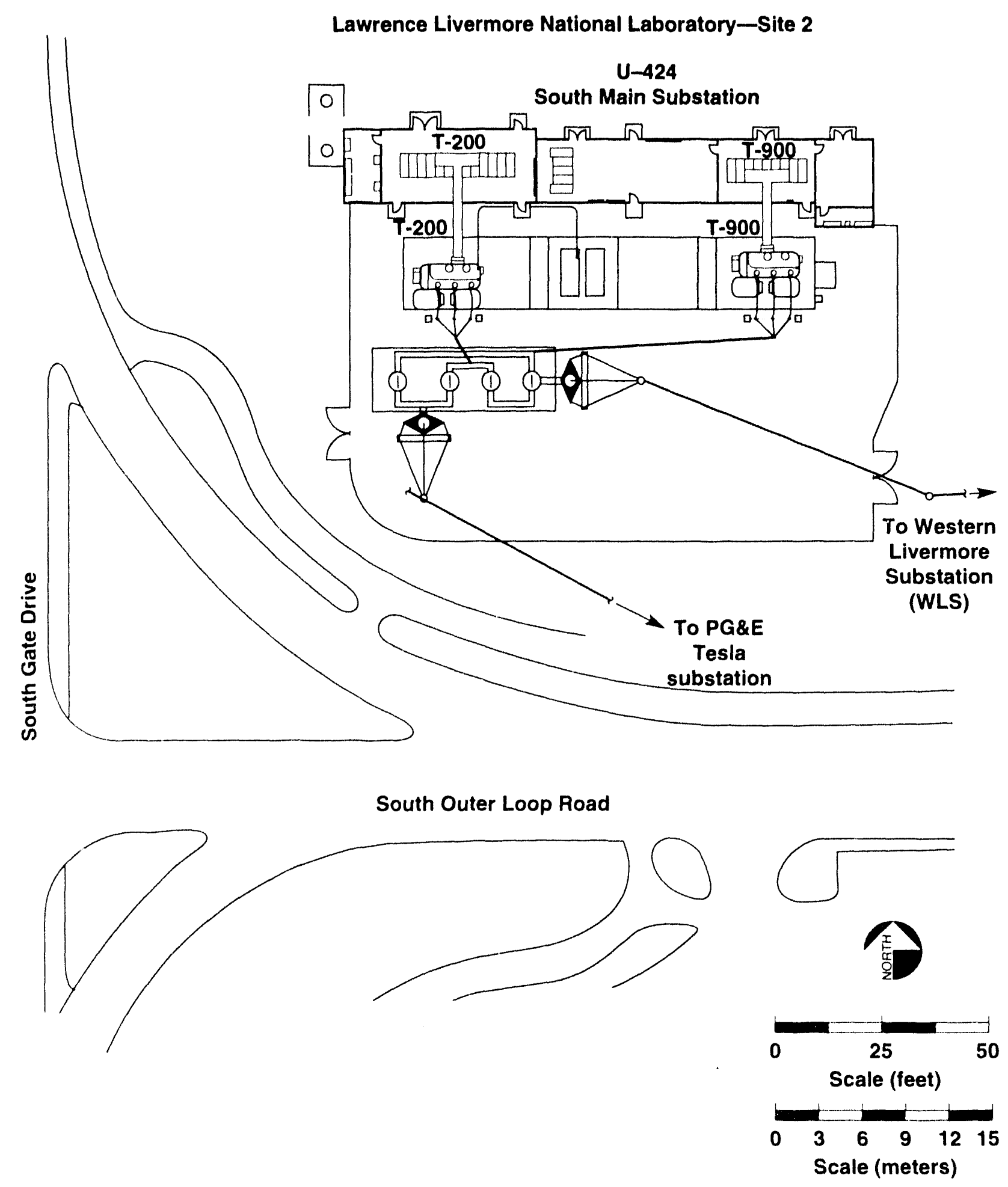

Fig. 11. Gas insulated substation (GIS) ring bus configuration. 

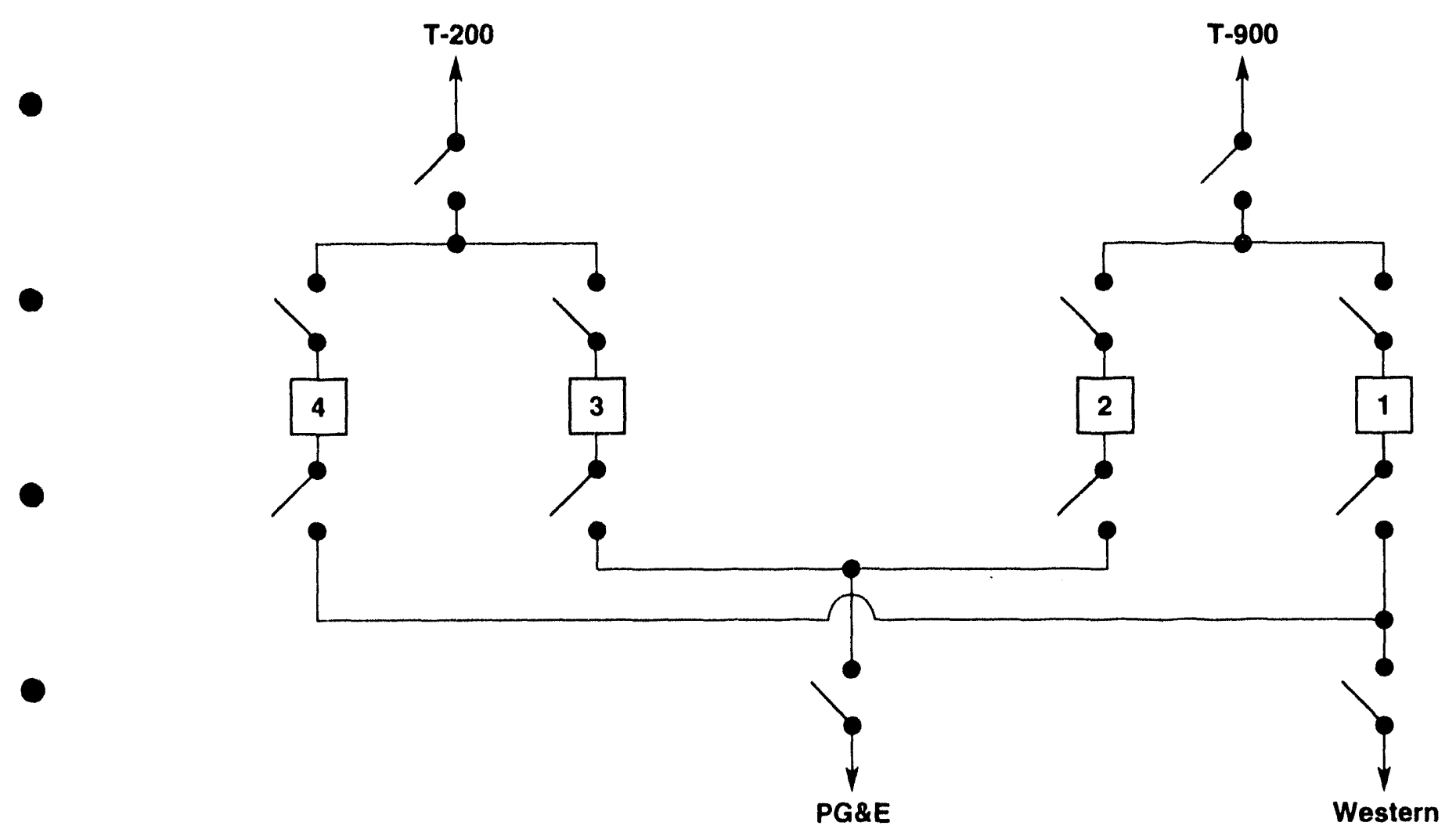

Fig. 12. GIS ring bus-single line. 


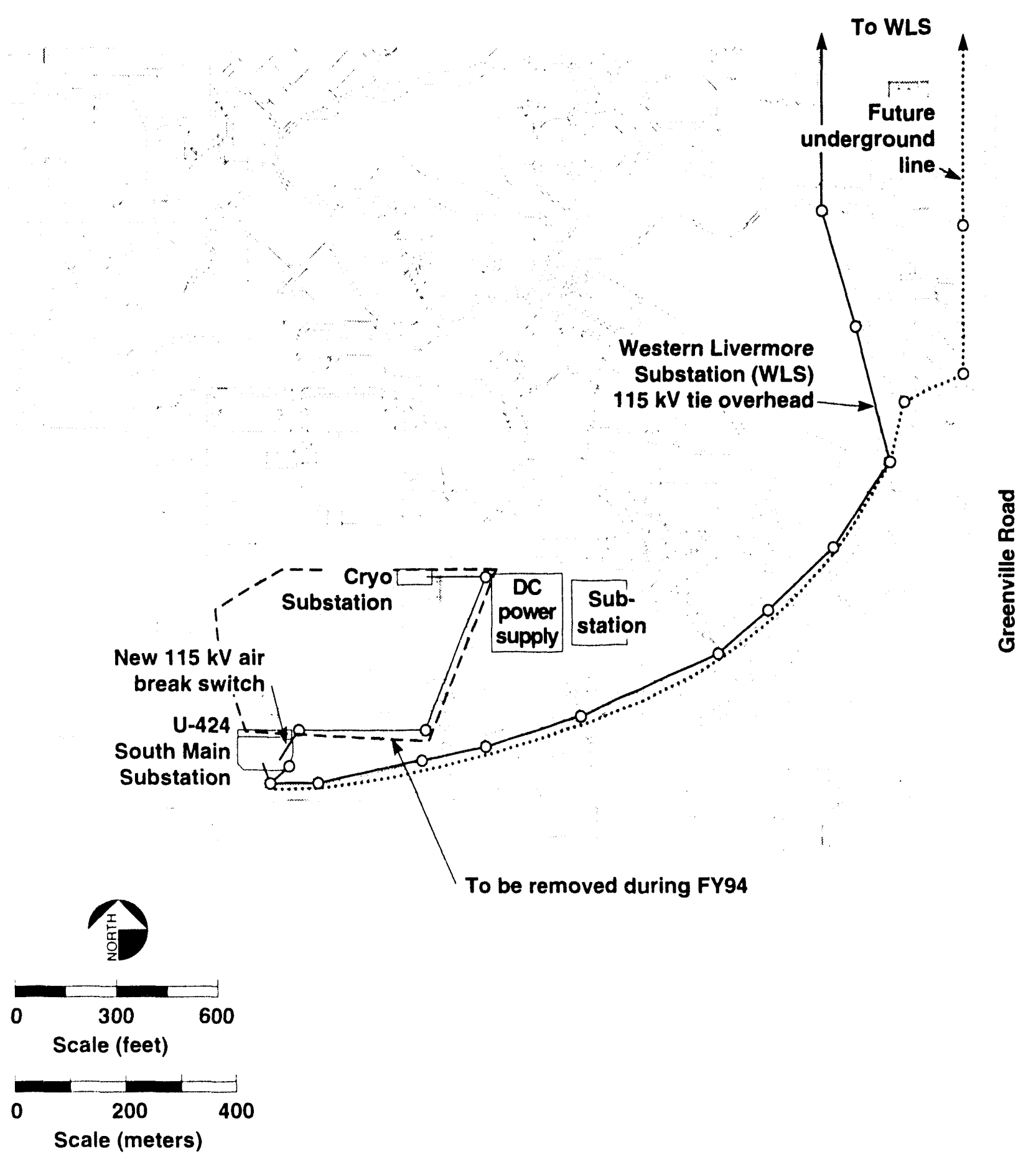

Fig. 13. The $115 \mathrm{kV}$ overhead line to Cryo, partial LLNL site plan. 


\section{Project 5.2-Load Grid Switchgear Assembly Additions}

\subsubsection{Project Description}

These projects will provide for the installation of five Load Grid Switchgear (LGS) assemblies and associated duct banks to replace six area fused substations. One assembly (LGS-37) has been installed to replace one fused substation. The new LGS assemblies are equipped with modern vacuum circuit breakers with relaying for protection. These relays will allow proper protection coordination from the supplying substations to the programmatic loads. This coordination cannot be achieved with the existing fused substation.

The LGS assemblies will have two express feeders as the source of power, one each from U-424 and WLS. Additionally, as a separate project and at a later date, (EPSRU II) LGS feeders to the programs will be reconfigured to the loop distribution style circuits required by DOE 6430.1A.

These projects include the relocation of existing power factor correction capacitors to each LGS location.

Figure 14 shows the proposed locations for each LGS. The locations have been selected based on existing and proposed load centers and will be sited in accordance with LLNL facility siting criteria.

The estimated cost for these projects is about $\$ 16.5$ million with a tentative construction calendar in FY94 and 95. The EPSRU Line Item and Western will fund these projects. 


\section{Patterson Pass Road}
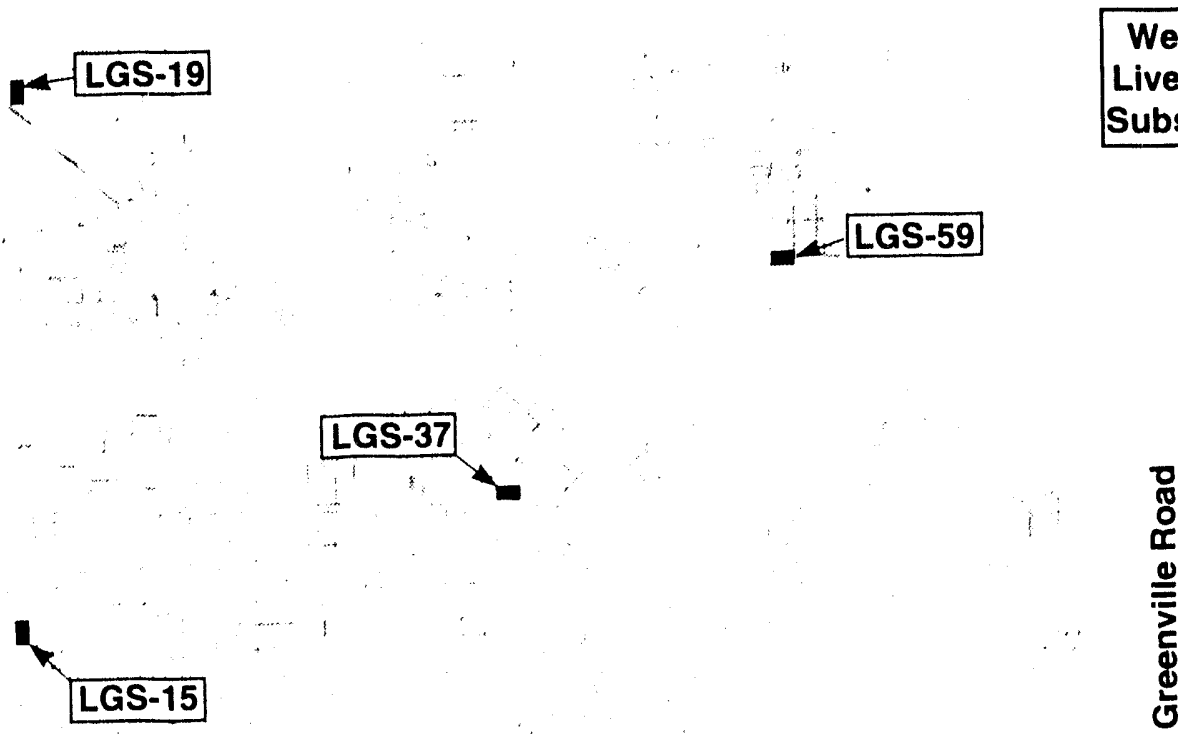

0
0
0
0
0
0
5
5
5
5
0
0

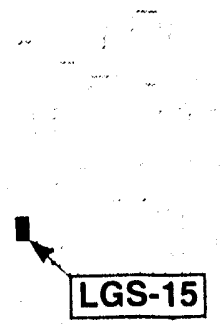

\section{LGS-14}

\section{East Avenue}

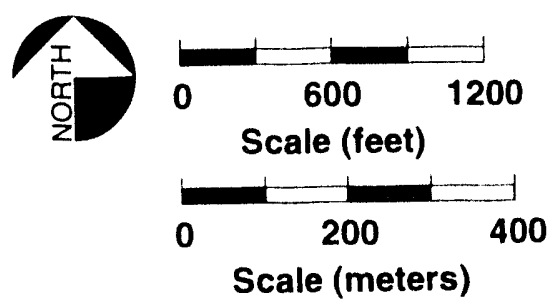

Fig. 14. LGS site layout plan. 


\section{Project 5.3-13.8 kV Underground Duct Bank and Manhole Distribution System}

\subsubsection{Project Description}

This project provides for the installation of a $13.8 \mathrm{kV}$ underground duct bank and manhole system throughout the site from the WLS and U-424 to each of the LGS assemblies, which in turn connect to distribution feeders that serve the facility load centers. The underground duct bank system is one of the key elements for distributing power throughout the site.

The usable sections of existing duct banks and associated manholes will be incorporated into the system being installed under this project.

Figure 15 indicates the proposed underground duct and manhole system. The duct bank system is being located along existing utility corridors wherever feasible, and any offsets will be in accordance with LLNL facility siting criteria. Since the duct bank and manhole system is underground and will be located, generally, along existing corridors, there will be minimal permanent impact upon aboveground facilities.

Manholes being installed under this project will be $9 \mathrm{ft} \times 12 \mathrm{ft} \times 9 \mathrm{ft}$ deep. Duct banks will contain 6-inch conduit and will vary from fourway to 12-way. Some sections of the underground system will contain parallel duct banks, while other sections will contain single duct banks. Separation between the parallel duct banks will be designed to minimize the derating of the cable current-carrying capability. The choice of single or parallel duct banks and separation between duct banks was made after a detailed engineering study. Minimum depth below grade will be maintained throughout the system in order to conform to the National Electrical Code (NEC).

The duct banks shall contain spare conduit. Additionally, two sets of 4 -inch conduit will be installed for use in communications and protection circuitry.

To select routes for the underground electrical distribution system and avoid existing congested areas wherever possible, many items were considered. One of the items was an alternate layout of the present $13.8 \mathrm{kV}$ underground duct bank system along Avenue $B$. This possibility was studied but not recommended because of the additional cost and the potential difficulty of installing the duct banks and manholes in this already congested utility corridor.

The funding for this project is included with Project 5.2. 

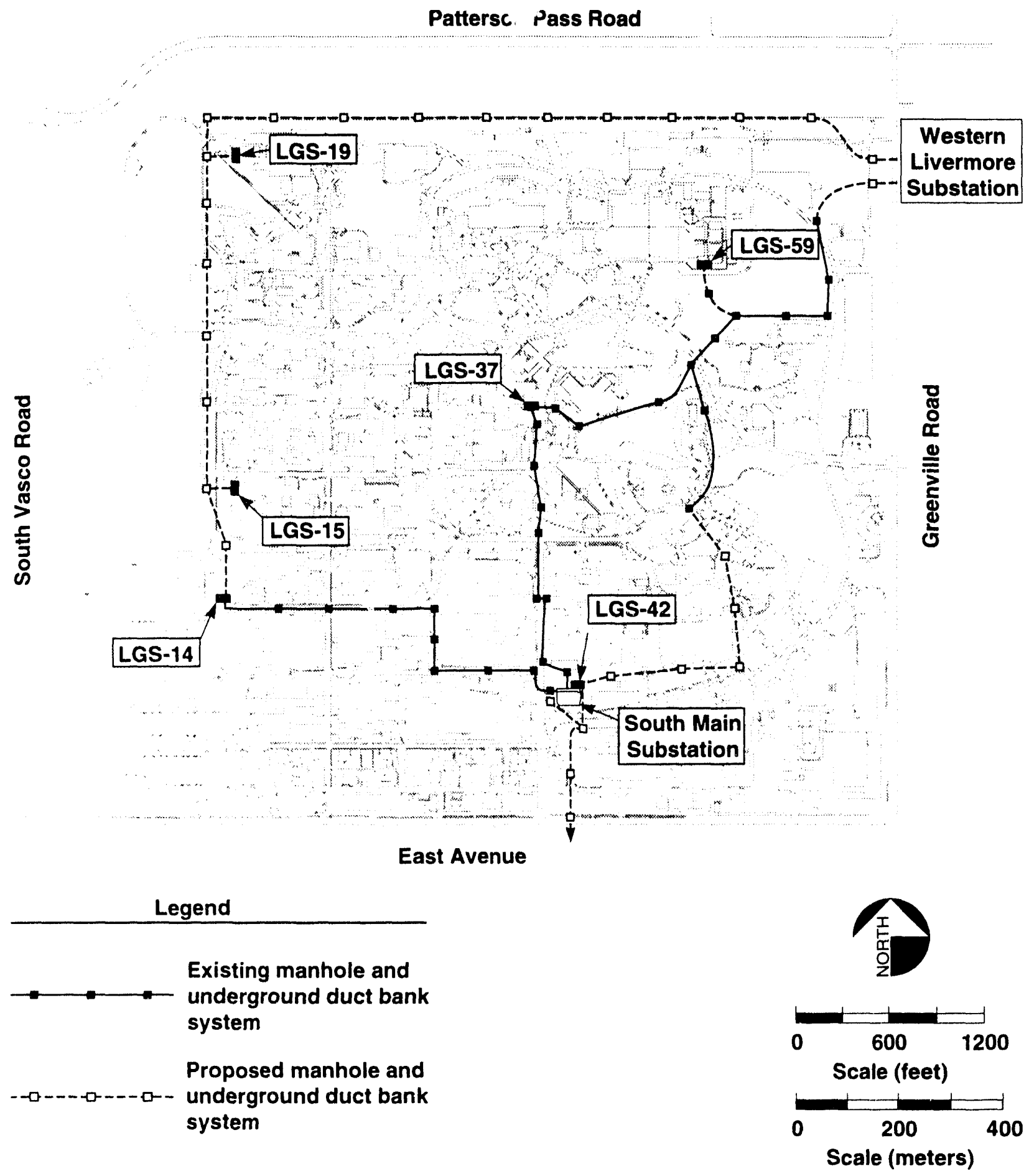

Fig. 15. The $13.8 \mathrm{kV}$ underground duct bank system layout. 


\section{Project 5.4-13.8 kV Express Feeders-Phase 1}

\subsubsection{Project Description}

This project provides for the installation of $13.8 \mathrm{kV}$ express feeders in the underyround duct bank system which is to be installed under Project 5.3. The feeders will be installed from the WLS to five Load Grid Switchgear assemblies, LGS-14, LGS-15, LGS-19, LGS-37, and LGS-59, as indicated on Figures 15 and 16.
The express feeders will consist of multiple $750 \mathrm{KCM}$, EPR cables that terminate on $1200 \mathrm{~A}$ circuit breakers in the WLS and in each of the five LGS assemblies. Splices will be installed on the cables only where required.

The estimated cost of this project is $\$ 4.2$ million and is included in the $\$ 16.5$ million for Project 5.2.

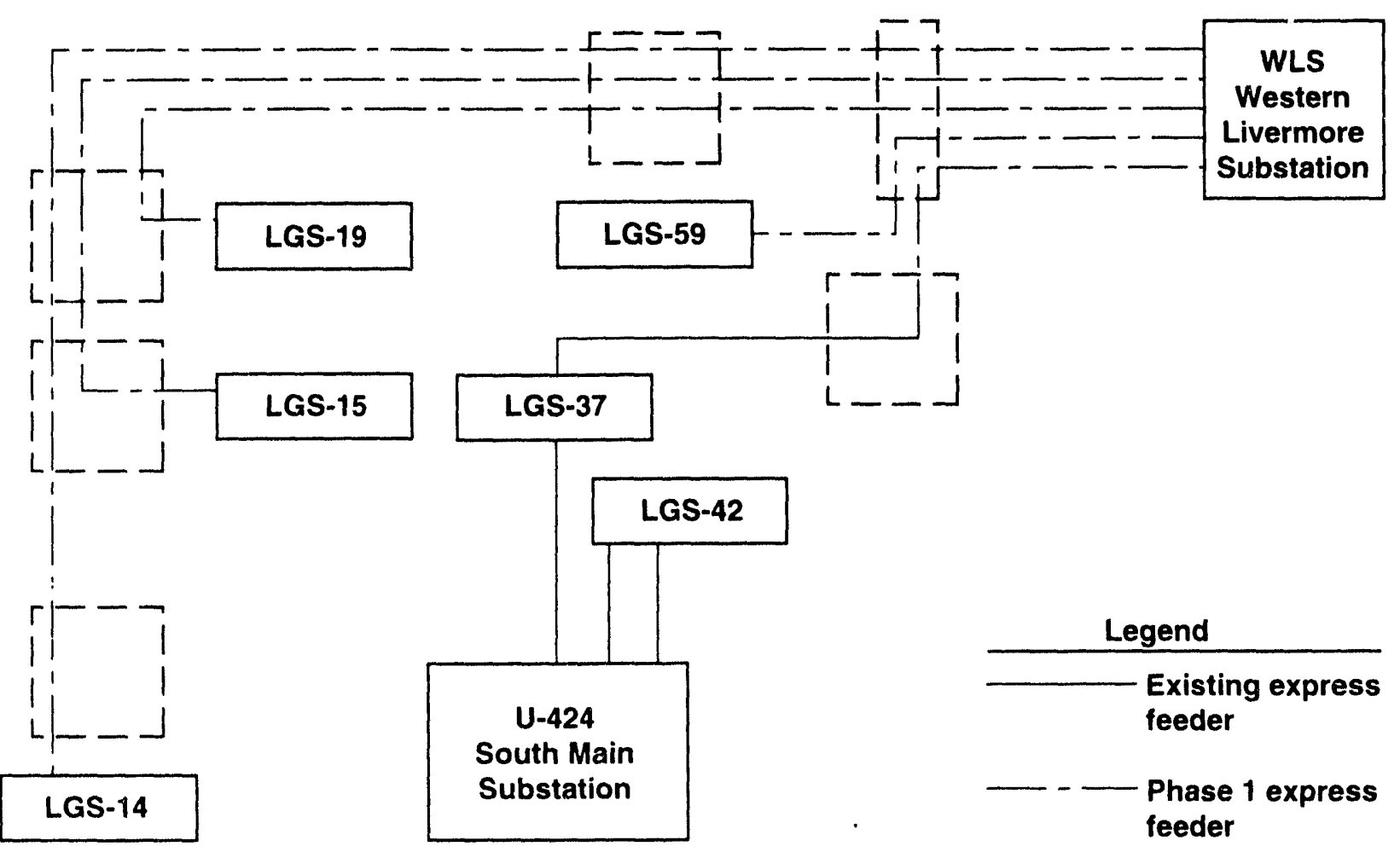

Fig. 16. Arrangement of the $13.8-\mathrm{kV}$ express feeder-phase 1 . 


\section{Project 5.5-13.8 kV Express Feeders-Phase 2}

\subsubsection{Project Description}

This project provides for the installation of $13.8 \mathrm{kV}$ express feeders in the underground duct bank system which is to be installed under Project 5.3. The feeders will be installed from U-424 to four LGS assemblies: LGS-14, LGS-15, LGS-19, and LGS-59, as indicated on Figure 17.

After the intital set of $13.8 \mathrm{kV}$ express feeders are installed under Project 5.4, each of the Load Grid Switchgear assemblies will be served by a single express feeder from the WLS. This single feeder, or radial-type system, will not have a backup and will require an outage(s) for repair and maintenance. Implementation of the second set of express feeders will permit uptime repair and maintenance and provide an alternate feeder for each LGS assembly. The second set of feeders will increase system reliability in that an automatic transfer scheme will be utilized to transfer an LGS assembly (or assemblies) from the primary feeder, or vice versa, in the event of a fault or loss of voltage on either feeder, thereby minimizing power outages as well as outage duration.

This second express feeder fulfills the basic requirement of DOE Order 6430.1A that facilities designated as critical shall be served by dedicated redundant circuits.

The alternate feeder also takes full advantage of the rebuilt U-424 and the new WLS. In the event of an outage at either of the main substations or an interruption in the distribution system from either of the main substations to any of the six LGS assemblies, a costly unscheduled outage would occur which could affect large areas of the site. In addition, feeder and equipment maintenance requires downtime, and any downtime adversely affects the programmatic efforts. The installation of the second feeder to each of the LGS assemblies would eliminate most of the scheduled or unscheduled outages and, as clearly indicated by past experience, would be cost-effective.

The project is funded by the EPSRU line item.

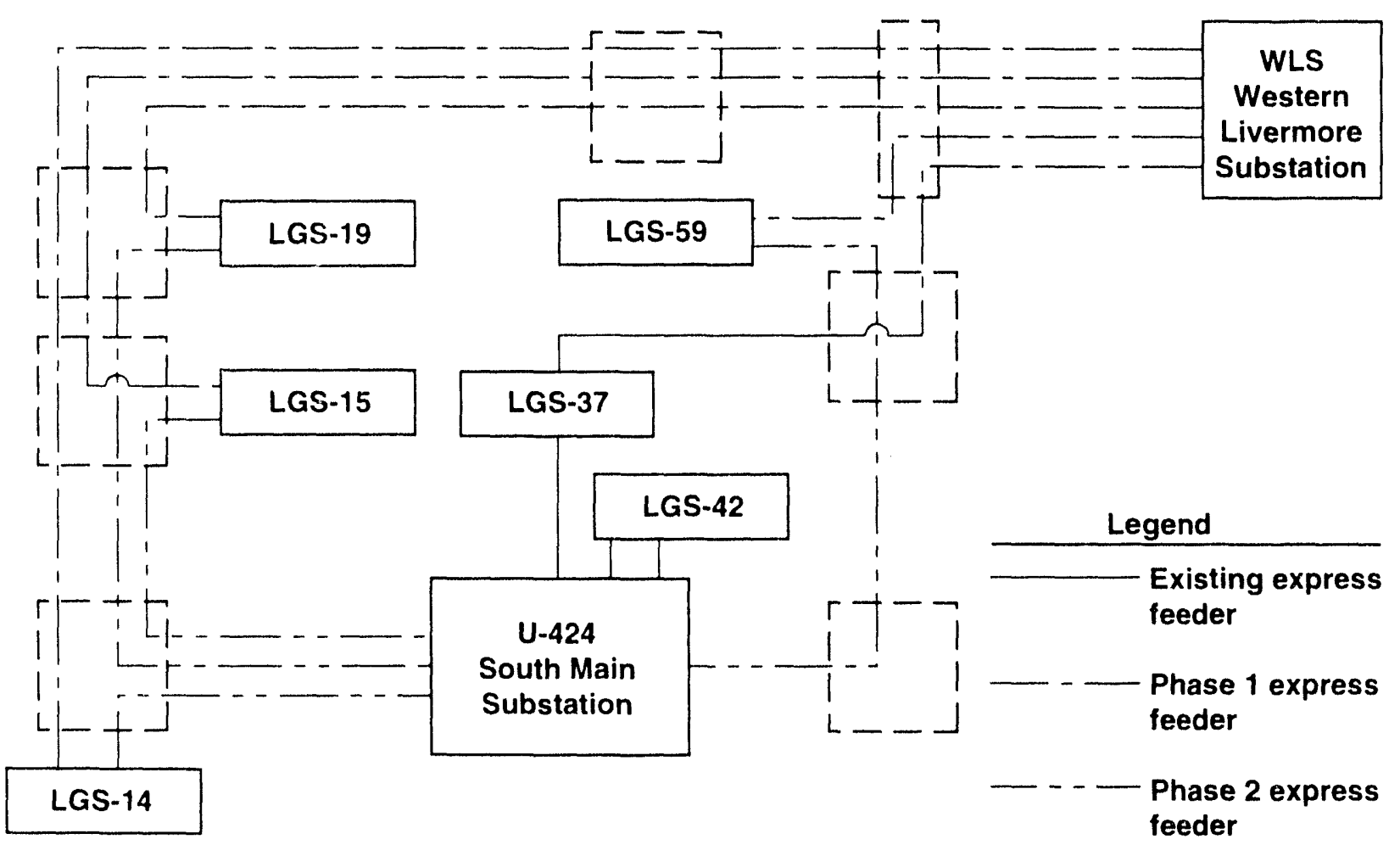

Fig. 17. Arrangement of the 13.8-kV express feeder-phase 2. 


\section{Project 5.6-Electrical Code Improvements}

\subsubsection{Project Description}

This Project consists of electrical code improvements to the $115 \mathrm{kV}$ and $13.8 \mathrm{kV}$ electric system essentially derived from a Kaiser Engineers survey and report, dated February 1989 (see Appendix A). The study was based on a Code Compliance Survey of the high and medium voltage electric systems at the site, at an estimated cost of approximately $\$ 4.4$ million and is funded by EPSRU.

The project is separate from Projects 5.7 and 5.8, which also constitute electrical code improvements. Those two projects apply specifically to replacement of low voltage feeders and panelboards in buildings.

This project provides the first component of electrical code improvements which are to be conducted in facilities at the site within the fiveyear plan.

The Kaiser survey was performed in order to provide a basis for defining the items in the high and medium voltage systems that required corrections. A subsequent cost for the individual items was developed from the survey results.

\section{Project 5.7-Unreliable and Overstressed Low Voltage Panelboard Replacement}

\subsubsection{Project Description}

In buildings at the site, a field survey and a short circuit study has been made of the 535 panelboards having $1500 \mathrm{kVA}$ and larger transformers at the 480 volt level and $1000 \mathrm{kVA}$ and larger at the 208 volt level. It has been determined that 251 of these panelboards are underrated and unable to interrupt short circuit faults. This is a violation of the NEC, as well as DOE Order $6430.1 \mathrm{~A}$ requirements.

The likelihood of panelboard and circuit breaker failures is increasing. This could result in electrical power disruptions to service and safety hazards to personnel. Breakers are becoming old and obsolete, and some have become nonoperational. Failures will affect large areas in the buildings and require considerable service outage time for repair and replacement.

It is planned that all 251 panelboards be replaced under this project.

The es . mated cost of this project is $\$ 3.1$ million and is funded by EPSRU. 


\section{"roject 5.8-Unreliable Low Voltage Feeder Replacement}

\subsubsection{Project Description}

A survey has been made of existing feeders in almost all buildings 25 years or older. The feeders to 21 buildings were found to be seriously deteriorated and obsolete.

If not replaced, insulation failures and deteriorations of these feeders will cause increased cable faults and create safety and shock hazards to operating persor nel, as well as increased downtime affecting programmatic service.

It is proposed that the 180 feeders in the 21 buildings identified be replaced under this project.

The estimated cost of the project is $\$ 4.0$ million and is funded under EPSRU.

\section{Project 5.9-Install SCADA System}

\subsubsection{Project Description}

This project will install a Supervisory Control and Data Acquisition (SCADA) system at LLNL. The installation of the express $13.8 \mathrm{kV}$ feeders, LGSs and new switching facilities at U-424 and WLS is intended to provide normal service for the Laboratory. The state-of-the-art relaying protection offered by these projects will assure maximum reliability and minimum damage if a fault should occur.

The SCADA system will provide a means for the electric distribution system operator to efficiently provide the following:

- Early identification and resolution of electrical distribution system problems.

- Load transfers from one primary express feeder to another remotely without an outage.

- Optimize the system to safely operate closer to ratings without overloading.
- Information for post-disturbance analysis and load forecasting.

The SCADA system also provides real-time data collection and storage of all monitored load parameters, allowing the planning department access to all system loads such as watts, vars, current, voltage, power factor and DC power availability.

Initially the SCADA system will be installed at U-424, WLS (13.8 kV distribution bus), and the six LGS installations. For a diagram of the SCADA concept and proposed funding sources, see Figure 18.

- The SCADA master control room will be installed in B-517.

- Projects installing new facilities will contain SCADA equipment in the design.

- A SCADA system will also be installed at Site 300. 
Supervisory Control and Data Acquisition (SCADA)

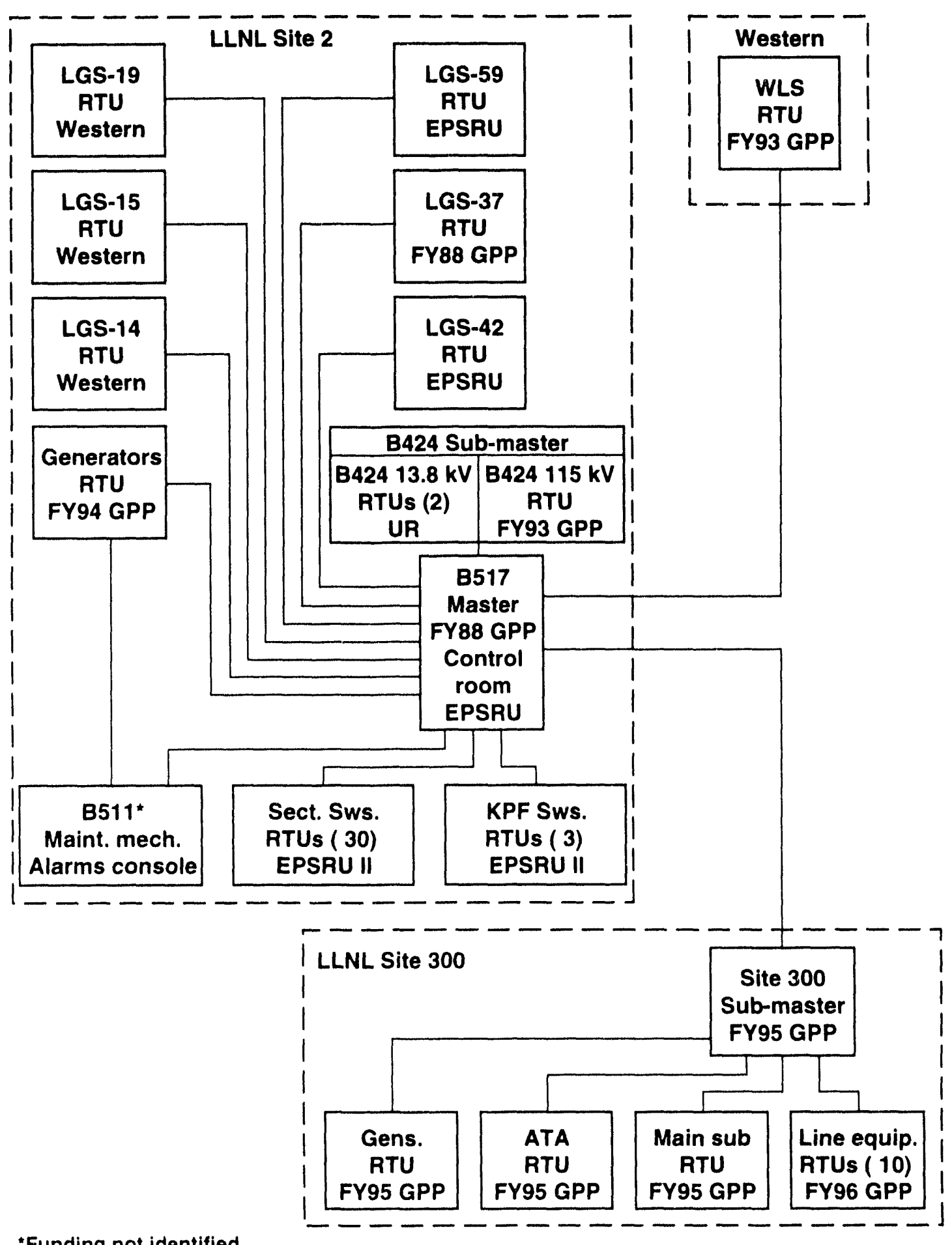

"Funding not identified

Fig. 18. Arrangement of the SCADA concept. 


\section{Project 5.10-Eliminate $12 \mathrm{kV}$ Distribution}

\subsubsection{Project Description}

This project provides for replacement of the 40- to 50-year old, $12 \mathrm{kV}$ overhead distribution system with an underground $13.8 \mathrm{kV}$ system.

The overhead system has reached the end of its life cycle, and the chances of catastrophic failure increase as it continues to age. The service reliability of the overhead system has not been good. Numerous outages, due to birds and wind, have occurred. Placement of the system underground will resolve its exposure to those elements.
Numerous programmatic loads are served from this system, and they require highly reliable power to successfully complete their assigned missions.

The existing $12 \mathrm{kV}$ overhead system is a radial type, and DOE requirements call for redundant feeds. When placed underground, a loop-style design will be accomplished.

Funding will be accomplished through the GPP process.

\section{Project 5.11-Distribution Automation}

\subsubsection{Project Description}

This project provides for adding SCADA control to existing and future sectionalizing switches. Manually operated switches will be provided with motor operators and mini Remote Terminal Units (RTU) will be added as necessary. This will dramatically reduce the outage time to our programmatic customers.
Upon completion of Project 5.9, the main substation and the LGSs will be SCADA controlled. This will allow not only automatic data acquisition but will also a'low for load transfers for maintenance purposes. The completion of Project 5.11 will allow automatic control for the balance of the distribution system.

This project will be GPP funded.

\section{Project 5.12-Voltage Conversion to $13.8 \mathrm{kV}$}

\subsubsection{Project Description}

This project will convert the 11 remaining $12 \mathrm{kV}$ transformers to $13.8 \mathrm{kV}$ primary service.

The ages of equipment on the $12 \mathrm{kV}$ system vary from 40 to 50 years. The system is beyond its design life expectancy and is subject to failure.

The only remaining $12 \mathrm{kV}$ source, at $\mathrm{T}-800$, failed on its last $12 \mathrm{kV}$ outage. When that occurred, the alternate source, $T-300$, was still available for use. T-300 has since been removed.
Consequently, an outage exceeding 24 hours would be very likely if another $12 \mathrm{kV}$ outage should occur.

Conversion to $13.8 \mathrm{kV}$ will provide as many as four feeder circuits to feed the area. This would significantly reduce the downtime to the programmatic loads.

This project will be GPP funded. 


\section{Appendix A-Studies and Reports}

\section{Identification of Previous Studies and Reports}

The following is a list of related studies and reports that have been prepared for and by Lawrence Livermore National Laboratory:

Conceptual Design Report, Electrical Power System Replacement and Upgrades (EPSRU) line item, dated February 1989.

Survey and Report: High Voltage Power Distribution System by Kaiser Engineers, dated February 1989.

Report of the Evaluation Committee on LLNL Electrical Power Distribution System, dated March 1989.

Western Area Power Administration Electrical Safety Review, November 1989.

Supplement to the Report of the Evaluation Committee on LLNL Electrical Power Distribution System, dated December 1989.

Electrical Distribution System Peer Review Report by C\&L Value Associates, dated December 1989.

Short circuit and load flow studies on the $115 \mathrm{kV}, 13.8 \mathrm{kV}$ and $12 \mathrm{kV}$ systems by Applied Power, dated January 19, 1990.

Enzironmental Assessment for the Electrical Utility System Distribution Replacement and Upgrade, dated October 1991.

\author{
LLNL Site Development Plan, dated \\ April 1992.
}

Site 300 Site Development Plan, dated April 1991.

Coordination studies for the protective devices on $115 \mathrm{kV}, 13.8 \mathrm{kV}$ and $12 \mathrm{kV}$ systems by Applied Power, April 8, 1990.

Conceptual Design Report, Electrical Code Improvements line item, dated March 1990.

Report on the current-carrying capability of the $13.8 \mathrm{kV}$ express feeders installed in the underground manhole and duct bank system associated with six LGS installations as well as the alternate seven LGS and eight LGS installations. Several reports dated January through March 1990) were issued. Reports were based on the WE-8O Computer Program, "Calculation of current-carrying capability of $13.8 \mathrm{kV}$ cables in underground duct banks," by West Coast Engineering, Inc.

Electrical Risk Analysis prepared by Impell Corporation, dated January 1990.

Report on the Comparison of $115 \mathrm{kV}$ Breaker Configurations in the South Main Substation, dated October 1990. 

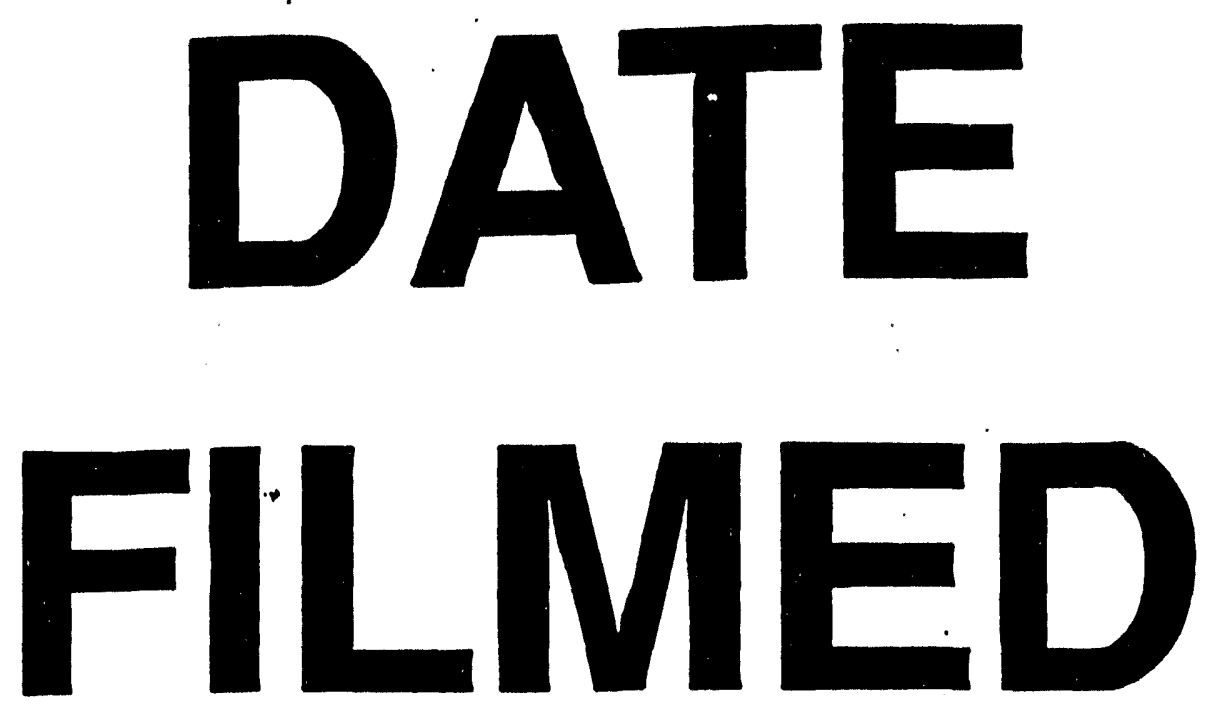

$2 / 16 / 94$
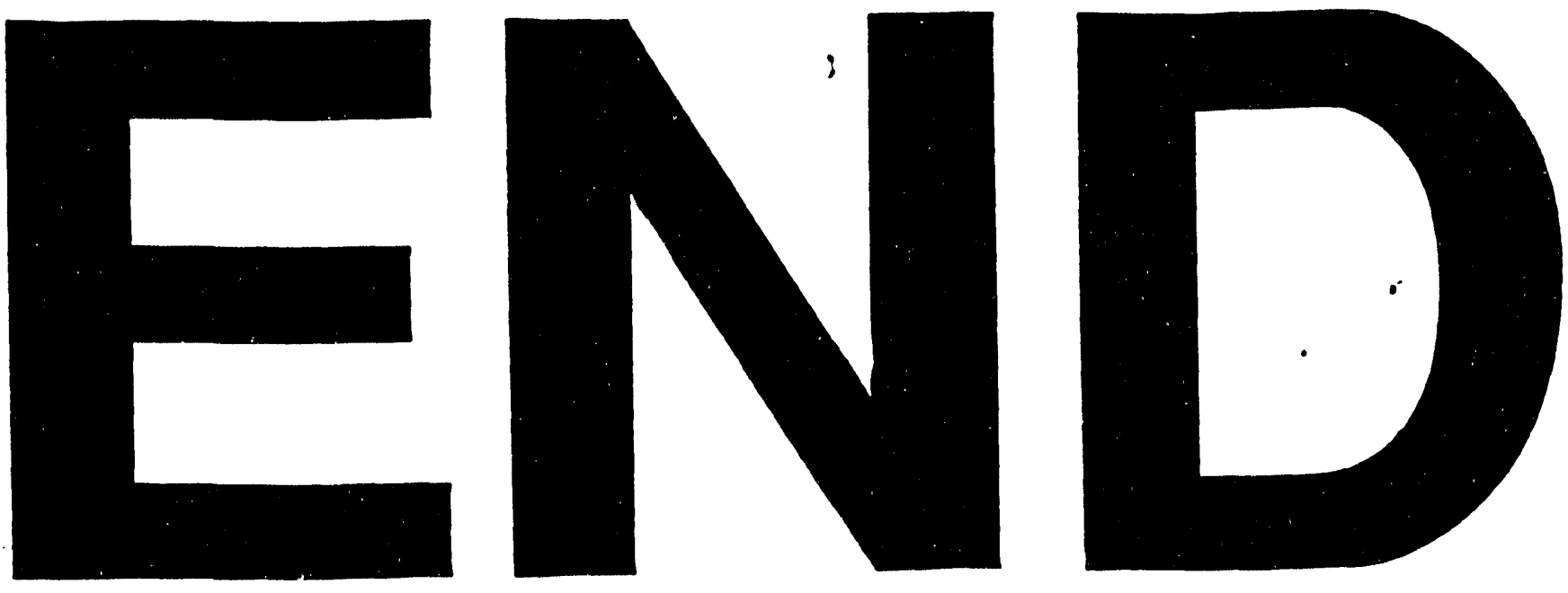


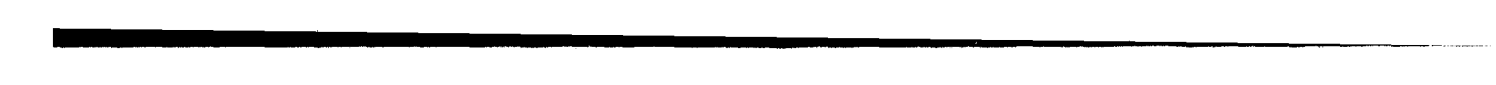

